Int. J. Dev. Biol. 59: 341-355 (2015)

doi: $10.1387 / \mathrm{ijdb} .150211 \mathrm{jp}$

\title{
Calcium signals regulated by NAADP and two-pore channels - their role in development, differentiation and cancer
}

\author{
JOHN PARRINGTON*, PAMELA LEAR and ALAA HACHEM \\ Department of Pharmacology, University of Oxford, Oxford, United Kingdom
}

\begin{abstract}
Ca}^{2+}$ signals regulate a wide range of physiological processes. Intracellular $\mathrm{Ca}^{2+}$ stores can be mobilized in response to extracellular stimuli via a range of signal transduction mechanisms, often involving recruitment of diffusible second messenger molecules. The $\mathrm{Ca}^{2+}$ mobilizing messengers Ins $\mathrm{P}_{3}$ and $\mathrm{cADPR}$ release $\mathrm{Ca}^{2+}$ from the endoplasmic reticulum via Ins $\mathrm{P}_{3}$ and ryanodine receptors, respectively, while a third messenger, NAADP, releases $\mathrm{Ca}^{2+}$ from acidic endosomes and Iysosomes. Bidirectional communication between the ER and acidic organelles has functional relevance for endolysosomal function as well as for the generation of $\mathrm{Ca}^{2+}$ signals. The two-pore channels (TPCs) are currently strong candidates for being key components of NAADP-regulated $\mathrm{Ca}^{2+}$ channels. $\mathrm{Ca}^{2+}$ signals have been shown to play important roles in embryonic development and cell differentiation; however, much remains to be established about the exact signalling mechanisms involved. Investigation of the role of NAADP andTPCs in development and differentiation is still at an early stage, but recent studies have suggested that they play important roles at key developmental stages in vivo and are important mediators of differentiation of neurons, skeletal muscle cells and osteoclasts in vitro. NAADP signals andTPCs have also been implicated in autophagy, an important process in differentiation. Moreover, potential links between TPC 2 and cancer have been recently identified. Further studies will be required to identify the precise mechanisms of action of TPCs and their link with NAADP signalling, and to relate these to their roles in differentiation and other key developmental processes in the cell and organism.
\end{abstract}

KEY WORDS: development, differentiation, cancer, calcium, endolyososmal, NAADP, two-pore channel

\section{Introduction}

The generation of new cells by cell division during embryo development is an essential attribute of multicellular life. An equally crucial aspect of development is the commitment of non-specialized embryonic stem cells and their subsequent differentiation into all the cell types of the organism. While less dramatic, growth and differentiation continue in adulthood, as part of the process of tissue repair and during normal cell turnover. Another central factor in embryogenesis is apoptosis, the process of programmed cell death, which shapes the morphology of the embryo during development and regulates cell numbers in adulthood (Lockshin and Zakeri2007). Autophagy, an intracellular mechanism involving degradation of unused or dysfunctional cellular components, is also central to the maintenance and survival of the organism (Mizushima and Levine 2010, Wu et al., 2013). Abnormalities in growth and differentiation can lead to cancer (Moustakas and Heldin 2007). As such, a better understanding of the mechanisms that control these processes

\begin{abstract}
Abbreviations used in this paper: ARGs, ADP-ribosyl cyclases; $\beta$-NAD ${ }^{+}, \beta$-nicotinamide adenine dinucleotide; $\mathrm{Ca}^{2+}$, calcium; $\left[\mathrm{Ca}^{2+}\right] \mathrm{i}$, cytoplasmic free $\mathrm{Ca}^{2+} ;\left[\mathrm{Ca}^{2+}\right] \mathrm{i}$, luminal $\mathrm{Ca}^{2+}$; CaM, calmodulin; CaMKII, $\mathrm{Ca}^{2+} / \mathrm{CaM}$-dependent protein kinase II; cAMP, cyclic AMP; cGMP, cyclic GMP; CICR, $\mathrm{Ca}^{2+}$-induced $\mathrm{Ca}^{2+}$-release; CREB, cAMP response element binding protein; DKO, double knockout; ER, endoplasmic reticulum; ESCs, embryonic stem cells; GPN, glycyl-L-phenylalaninebeta-naphthylamide; $\mathrm{Hs}_{\mathrm{s}}$ Homo sapiens; $\mathrm{IP}_{3}$, inositol 1,4,5 trisphosphate; $\mathrm{IP}_{3} \mathrm{Rs}$, inositol 1,4,5 trisphosphate receptors; MAPKs, mitogen-activated protein kinases; MEFs, mouse embryonic fibroblasts; MOs, morpholinos; mTOR, mammalian target of rapamycin; NAADP, nicotinic acid adenine dinucleotide phosphate; NCKX, $\mathrm{Na}^{+} / \mathrm{Ca}^{2+} / \mathrm{K}^{+}$exchanger; ncRNAs, non-coding RNAs; $\mathrm{NCX}, \mathrm{Na}^{+} / \mathrm{Ca}^{2+}$

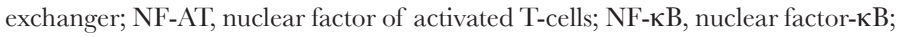
$\mathrm{PI}(3,5) \mathrm{P}$ 2, phosphatidylinositol 3,5-bisphosphate; PKC, protein kinase C; PMCA, $\mathrm{Ca}^{2+}$ ATPase; PTP, permeability transition pore; VOCGs, voltage-operated $\mathrm{Ca}^{2+}$ channels; ryanodine receptors (RyRs); SERCA, sarcoplasmic/endoplasmic reticulum $\mathrm{Ca}^{2+}$ ATPase; SOCE, store-operated $\mathrm{Ca}^{2+}$ entry; STIM1, stromal interaction molecule 1; Sp, Strongylocentrotus purpuratus; SR, sarcoplasmic reticulum; MCU, mitochondrial $\mathrm{Ca}^{2+}$ uniporter; TPGs, two-pore channels; VEGF, vascular endothelial growth factor; WT, wild type.
\end{abstract}

\footnotetext{
*Address correspondence to: John Parrington, Department of Pharmacology, University of Oxford, Mansfield Road, Oxford, OX1 30T, United Kingdom. E-mail: john.parrington@pharm.ox.ac.uk
}

Accepted: 20 July 2015.

ISSN: Online 1696-3547, Print 0214-6282 
can improve our understanding of how developmental disorders arise, and lead to new methods of diagnosing and treating cancer.

During human embryo development, a single fertilized egg gives rise to an adult containing approximately 100 trillion cells encompassing around 200 different cell types that with a few exceptions (e.g. red blood cells and B- and T-lymphocytes) each contain the same genomic DNA sequence. The many and varied differences in shape, size and functional characteristics of different cell types are due to highly controlled modifications of gene expression. Differences in gene expression in different cell types are due to their possession of different transcription factors, differential methylation of the genome, and to histone modification states (de Pretis and Pelizzola 2014). Increasingly, there is also recognition that noncoding RNAs (ncRNAs) can regulate gene expression (Morris and Mattick 2014). Such epigenetic changes can play both activatory and inhibitory roles in this process (de Pretis and Pelizzola 2014).

Epigenetic control of gene expression is itself tightly linked to the signalling pathways of the organism. On the one hand extracellular signalling molecules, such as hormones, growth factors, cytokines and neurotransmitters, convey messages between different parts of the organism through the blood and extracellular fluid. On the other, intracellular signalling pathways can involve both ionic and chemical changes in the cell. Typically, a second messenger such as cyclic AMP (cAMP) causes changes in the cell by activating a protein effector, in this case protein kinase $A$, that acts to phos- phorylate other target proteins and thereby change their activity (Blumenthal, 2012). Other small molecule second messengers include cyclic GMP (cGMP), inositol 1,4,5 trisphosphate $\left(\mathrm{IP}_{3}\right)$, and nicotinic acid adenine dinucleotide phosphate (NAADP); second messengers can also be gases such as nitric oxide, as well as ions, such as calcium ions $\left(\mathrm{Ca}^{2+}\right)$. It is particularly with the role that $\mathrm{Ca}^{2+}$ signals play in the control of differentiation and development that this review will be concerned, and more specifically with the role played by the second messenger NAADP, which recent studies have shown to be a key regulator of a particular type of $\mathrm{Ca}^{2+}$ signals emanating from the endolysosomal compartment, via the action of a new class of ion channels called the two-pore channels (TPCs) (Zhu et al., 2010, Patel et al., 2011).

\section{$\mathrm{Ca}^{2+}$ signals - modulators of physiological processes}

Changes in intracellular $\mathrm{Ca}^{2+}$ regulate a diverse range of celIular processes including fertilization, proliferation, differentiation, contraction, secretion, exocytosis, metabolism, gene transcription and apoptosis (Berridge et al., 2003). Cells express a number of effector proteins that bind $\mathrm{Ca}^{2+}$ specifically, reversibly and with affinities that allow them to respond to $\mathrm{Ca}^{2+}$ at physiological signalling concentrations; these effectors modulate a wide variety of $\mathrm{Ca}^{2+}$-sensitive cellular processes (Carafoli et al., 2001, Clapham 2007). Various conserved $\mathrm{Ca}^{2+}$-binding motifs on proteins give them

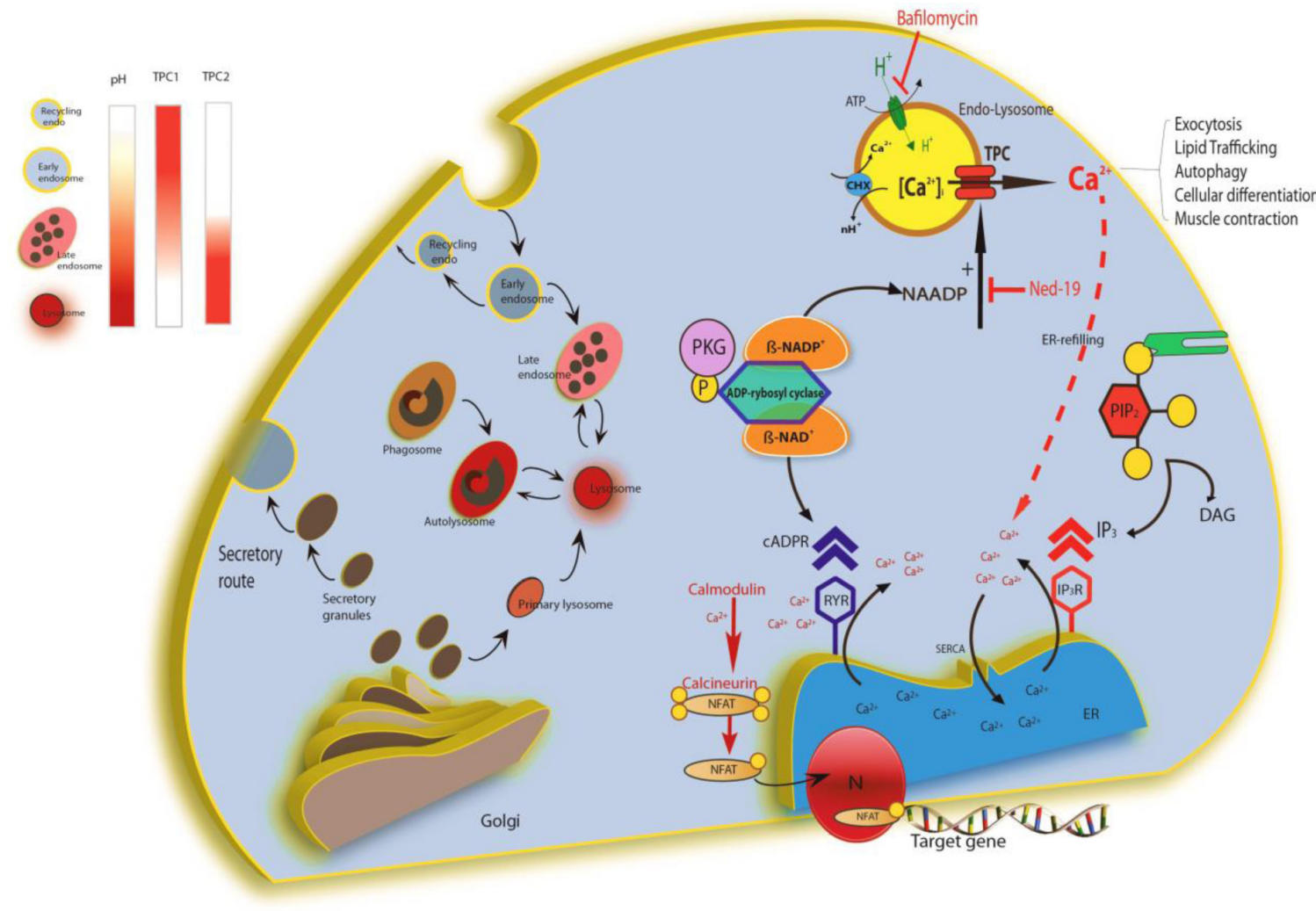

Fig. 1. Schematic representation of a cell depicting $\mathrm{Ca}^{2+}$ release from the endoplasmic reticulum (ER) via inositol trisphosphate receptors $\left(\mathrm{IP}_{3} \mathrm{R}\right)$ and ryanodine receptors (RyR) in the presence of inositol 1,4,5-trisphosphate $\left(\mathrm{IP}_{3}\right)$ and cyclic ADP-ribose (cADPR) respectively. $I P_{3}$ is the by-product of phosphatidylinositol 4,5-bisphosphate (PIP $)$ hydrolysis by phospholipase C (PLC), whereas CADPR is produced from nicotinamide adenine dinucleotide $\left(N A D^{+}\right)$by ADP-ribosylcyclase. In the endolysosomal system, NAADP elicits $\mathrm{Ca}^{2+}$ release from the acidic stores, lysosomes and endosomes, via the two-pore channels (TPCS). This signalling pathway plays important roles in exocytosis, lipid trafficking, autophagy, cellular differentiation, and muscle contraction. Local $\mathrm{Ca}^{2+}$ release by NAADP can trigger global $\mathrm{Ca}^{2+}$-induced $\mathrm{Ca}^{2+}$-release (CICR) responses from the ER or increase ER Ca ${ }^{2+}$ uptake by sarco/endoplasmic reticulum Ca ${ }^{2+}$-ATPase (SERCA). Changes in intracellular Ca ${ }^{2+}$ ion concentration are also responsible

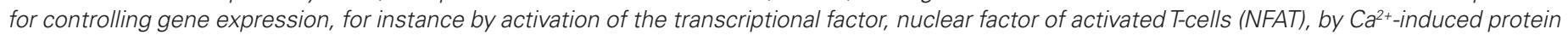
phosphorylation of calcineurin. The left side of the diagram shows the relative density of TPC1 and TPC2 isoforms in endosomes and lysosomes relative to the level of the acidity in these organelles. Gradients represent relative density of TPC1 or TPC2 or the acidity of the organelles. 
their $\mathrm{Ca}^{2+}$ sensitivity. EF-hands are one such motif, being found in a wide range of proteins with a variety of different functions, including regulators of transcription, contraction and apoptosis (Gifford et al., 2007). As well as the direct sensitivity conveyed by an effector protein containing an EF-hand, sensitivity to $\mathrm{Ca}^{2+}$ can be achieved indirectly via association with the EF-hand-containing protein calmodulin (CaM), which functionally regulates hundreds of proteins (Carafoli et al., 2001, Clapham 2007). The C2 domain is another $\mathrm{Ca}^{2+}$-binding motif found in many hundreds of proteins including protein kinase $\mathrm{C}$ (PKC) and phospholipases; it mediates $\mathrm{Ca}^{2+-i n d u c e d ~ t r a n s l o c a t i o n ~ t o ~ t h e ~ p l a s m a ~ m e m b r a n e ~(C a r a f o l i ~ e t ~}$ al., 2001, Clapham 2007).

An important feature of $\mathrm{Ca}^{2+}$ signals is their range of spatiotemporal properties. Thus, while a single $\mathrm{Ca}^{2+}$ spike can trigger $\mathrm{Ca}^{2+}$-sensitive responses such as cardiac contraction and some exocytotic events, more sustained $\mathrm{Ca}^{2+}$ signals are required to trigger other processes, such as transcription and fertilization. Such sustained $\mathrm{Ca}^{2+}$ signals typically take the form of oscillations, with repeated spikes of increased intracellular $\mathrm{Ca}^{2+}$ concentration $\left(\left[\mathrm{Ca}^{2+}\right]\right.$ i); this minimises the cytotoxicity caused by sustained elevated cytoplasmic free $\mathrm{Ca}^{2+}$ and also allows transmission of information at the frequency as well as the amplitude of the signal (Berridge et al., 2003). Such frequency-encoded information is important for the control of gene expression by $\mathrm{Ca}^{2+}$, with different transcription factors being activated by different $\mathrm{Ca}^{2+}$ spike frequencies. Thus in Jurkat T-cells, low frequency $\mathrm{Ca}^{2+}$ oscillations can activate nuclear factor-kB (NF-kB); however nuclear factor of activated T-cells (NF-AT) and Oct/OAP require higher frequency stimulation for activation (Dolmetsch et al., 1997).

$\mathrm{Ca}^{2+} / \mathrm{CaM}-d e p e n d e n t$ protein kinase II (CaMKII), which modulates a wide range of cellular processes, has been shown to decode $\mathrm{Ca}^{2+}$ oscillation frequency information (De Koninck and Schulman 1998, Coultrap and Bayer 2012). Low frequency $\mathrm{Ca}^{2+}$ oscillations result in transient CaMKII kinase activity, while increasing the frequency results in increased levels of sustained activity, which persist after cessation of the $\mathrm{Ca}^{2+}$ signal information (De Koninck and Schulman 1998, Coultrap and Bayer 2012). In addition to its effects on transcription factors, CaMKII has recently been shown to exert effects on gene expression through phosphorylation of histones (Kreusser and Backs 2014).

While past studies have focused on the $\mathrm{Ca}^{2+}$-dependent modulation of protein effectors, it is now becoming clear that $\mathrm{Ca}^{2+}$ signals can also modulate expression and activity of ncRNAs such as microRNAs (Choi et al., 2014, Gstir et al., 2014, Harada et al., 2014), increasingly recognised as important players in the control of gene expression during embryonic development, by regulating processes such as cell proliferation, differentiation and apoptosis (Moreno-Moya et al., 2014).

\section{Generation of $\mathrm{Ca}^{2+}$ signals inside the cell}

While a simple ion like $\mathrm{Ca}^{2+}$ cannot be modified by common mechanisms of regulation of function such as phosphorylation, changes in $\mathrm{Ca}^{2+}$ signals are achieved by altering the balance between $\mathrm{Ca}^{2+}$ entry into and extrusion from the site of action, generally the cell cytoplasm, thus leading to a change in the intracellular concentration of $\mathrm{Ca}^{2+}$ (Berridge 2001). While [ $\left.\mathrm{Ca}^{2+}\right]$ i is maintained at around $100 \mathrm{nM}$ in resting cells, this can be increased to around $1 \mu \mathrm{M}$ on initiation of $\mathrm{Ca}^{2+}$ signalling (Berridge 2001). Sustained elevation of $\left[\mathrm{Ca}^{2+}\right]$ i precipitates phosphate, which is highly detrimental in a system that uses phosphorylation to modulate protein activity (Carafoli et al., 2001, Clapham 2007); it can also activate proteases, leading to cell death (Carafoli et al., 2001). Hence, mechanisms have evolved for removing $\mathrm{Ca}^{2+}$ from the cytosol, either by pumping it out of the cell, or sequestering it into intracellular stores. $\mathrm{Ca}^{2+}$ binding proteins such as parvalbumin, calsequestrin, calreticulin and calbindin also chelate $\mathrm{Ca}^{2+}$, thus limiting the duration and spatial range of its free diffusion in the cytosol (Berridge 2001, Clapham 2007)

$\mathrm{Ca}^{2+}$ is extruded from the cytosol into the extracellular medium by $\mathrm{Ca}^{2+}$ ATPase (PMCA), $\mathrm{Na}^{+} / \mathrm{Ca}^{2+}$ exchanger (NCX) and $\mathrm{Na}^{+} /$ $\mathrm{Ca}^{2+} / \mathrm{K}^{+}$exchanger (NCKX), all located in the plasma membrane (Berridge 2001). Sarcoplasmic/endoplasmic reticulum $\mathrm{Ca}^{2+}$ ATPase (SERCA), on the other hand, pumps $\mathrm{Ca}^{2+}$ into the endoplasmic reticulum (ER), which is present in most mammalian cell types, and in muscle cells into its equivalent, the sarcoplasmic reticulum (SR) (Clapham 2007). The nuclear envelope, an extension of the ER, also sequesters $\mathrm{Ca}^{2+}$ via SERCA(Carafoli etal., 2001). Mitochondria also act as buffers and stores of $\mathrm{Ca}^{2+}$, via the action of a number of specific proteins. Thus, $\mathrm{Ca}^{2+}$ uptake is mediated by the inner mitochondrial membrane-spanning mitochondrial $\mathrm{Ca}^{2+}$ uniporter (MCU) (Hoppe 2010, Pendin et al., 2014), while the mitochondrial $\mathrm{Na}^{+} / \mathrm{Ca}^{2+}$ exchanger extrudes $\mathrm{Ca}^{2+}$ (Nita et al., 2015).

In excitable cells, $\mathrm{Ca}^{2+}$ release into the cytosol can occur through plasma membrane voltage-operated $\mathrm{Ca}^{2+}$ channels (VOCCs), which undergo conformational changes upon membrane depolarisation, causing them to open and allow $\mathrm{Ca}^{2+}$ influx from the extracellular environment. Emptying of intracellular stores can also trigger $\mathrm{Ca}^{2+}$ entry across the plasma membrane, in both excitable and non-excitable cells, via store-operated $\mathrm{Ca}^{2+}$ entry (SOCE), which produces a $\mathrm{Ca}^{2+}$ release-activated $\mathrm{Ca}^{2+}$ current (ICRAC) (Lewis 2007, Wu et al., 2007). ERemptying is sensed by the ER membrane protein stromal interaction molecule 1 (STIM1), which responds by coming into close contact with the plasma membrane channel Orai1, activating it and thus causing $\mathrm{Ca}^{2+}$ influx (Feske 2007, Lewis 2007, Wu et al., 2007).

Intracellular $\mathrm{Ca}^{2+}$ stores can also be mobilised in response to extracellular stimuli via a range of signal transduction mechanisms, often involving diffusible second messenger molecules (Fig. 1). $\mathrm{Ca}^{2+}$ release from the endoplasmic reticulum (ER) occurs primarily via Ins: $\mathrm{P}_{3}$ receptors ( $\mathrm{IP}_{3} \mathrm{Rs}$ ) and ryanodine receptors (RyRs) (Berridge 2001). These can be activated by the second messengers $I P_{3}$ and cyclic ADP-ribose (cADPR), respectively, by extracellular stimuli, or by plasma membrane depolarisation in the case of RyR (Fig. 1). Release of $\mathrm{Ca}^{2+}$ from the nuclear envelope can also be triggered by $\mathrm{IP}_{3}$ and cADPR (Carafoli et al., 2001). The lipid sphingosine1-phosphate may also trigger ER $\mathrm{Ca}^{2+}$ release, although its status as a $\mathrm{Ca}^{2+}$ mobilizing messenger remains controversial (Young and Nahorski 2002). In addition, the endolyosomal system has recently become recognised as a major $\mathrm{Ca}^{2+}$ store (Morgan et al., 2011), a topic that we shall now discuss in detail.

\section{Acidic endolysosomal $\mathrm{Ca}^{2+}$ stores and NAADP}

The term 'endolysosomal organelles' describes acidic intracellular organelles, including early, late and recycling endosomes and lysosomes; secretory vesicles are also acidic, lysosomal-like organelles (Morgan et al., 2011, Shen et al., 2011). Early endo- 
somes are formed by plasma membrane endocytotic events; their lipid constituents may return to the plasma membrane via recycling endosomes, or proceed through the endolysosomal system, forming late endosomes and lysosomes (Fig. 1). During this progression, luminal $\mathrm{pH}$ decreases, while $\left[\mathrm{Ca}^{2+}\right]$ increases, from around $30 \mu \mathrm{M}$ in early endosomes (Gerasimenko et al., 1998; Morgan et al., 2011) to $500-600 \mu \mathrm{M}$ in lysosomes (Christensen et al., 2002, Lloyd-Evans et al., 2008, Morgan et al., 2011). Lysosomes sequester $\mathrm{Ca}^{2+}$ in a manner dependent on the low luminal $\mathrm{pH}$ of the organelles (Christensen et al., 2002), and disruption of lysosomal $\mathrm{Ca}^{2+}$ store mobilisation causes defects in lipid trafficking (Lloyd-Evans et al., 2008). The exact mechanism of endolysosomal $\mathrm{Ca}^{2+}$ uptake remains to be fully defined, but is likely to involve SERCA/PMCAlike ATPases (Morgan et al., 2011) and exchangers exploiting the proton gradient of acidic stores (Christensen et al., 2002). This is generated by the vacuolar $\mathrm{H}^{+}$ATPase; in addition, although simple $\mathrm{Ca}^{2+} / \mathrm{H}^{+}$exchangers are absent from the mammalian genome, $\mathrm{Ca}^{2+} /$ $\mathrm{Na}^{+}$exchangers might operate, with $\mathrm{Na}^{+}$gradients generated by coupled $\mathrm{Na}^{+} / \mathrm{H}^{+}$exchange (Patel and Docampo 2010, Morgan et al., 2011). Some $\mathrm{Ca}^{2+}$ also appears to be taken up into the endolysosomal system from the extracellular environment via endocytosis (Christensen et al., 2002, Morgan et al., 2011).

The evidence that $\mathrm{Ca}^{2+}$ signals generated from acidic, endolysosomal stores play important physiological roles has come primarily from studies of the second messenger NAADP, which have been carried out in both sea urchin eggs and egg homogenates, and in mammalian cells and tissues (Galione et al., 2011). Such studies have shown that NAADP is a highly potent $\mathrm{Ca}^{2+}$-releasing agent, being active at low nanomolar concentrations (Chini et al., 1995, Lee and Aarhus 1995). Unlike cADPR- and InsP $\mathrm{P}_{3}$-mediated $\mathrm{Ca}^{2+}$ release, NAADP-induced $\mathrm{Ca}^{2+}$ release is insensitive to changes in cytosolic $\mathrm{Ca}^{2+}$ concentration or $\mathrm{Ca}^{2+}$ chelation, indicating that the target receptor for NAADP is not subject to $\mathrm{Ca}^{2+}$-induced $\mathrm{Ca}^{2+}$ release (CICR) (Chini and Dousa 1996). In urchin egg homogenates, NAADP-evoked $\mathrm{Ca}^{2+}$ release is not affected by blockers of cADPRor $\mathrm{IP}_{3}$ - induced $\mathrm{Ca}^{2+}$ release, 8- $\mathrm{NH}_{2}-\mathrm{CADPR}$ or heparin (Lee and Aarhus 1995), ER Ca ${ }^{2+}$ depletion by thapsigargin (Genazzani et al., 1996), or prior $\mathrm{Ca}^{2+}$ release by cADPR or $\mathrm{IP}_{3}$ (Chini et al., 1995), but is desensitised by prior NAADP-induced $\mathrm{Ca}^{2+}$ release (Lee and Aarhus 1995). In addition, prior exposure to non-Ca ${ }^{2+}$-releasing concentrations of NAADP has been shown to desensitise urchin egg homogenates to subsequent release by activating concentrations (Genazzani etal., 1996). Asmall molecule-specific inhibitor of NAADP-mediated $\mathrm{Ca}^{2+}$ release, Ned-19, has also been developed (Naylor et al., 2009); studies of its binding properties indicate that the NAADP receptor possesses two NAADP binding sites, a highaffinity inhibitory site and a low affinity activatory site (Rosen et al., 2009), thus providing an explanation for the inhibitory effect of subthreshold NAADP.

The possibility that NAADP might target a $\mathrm{Ca}^{2+}$ store other than the ER was first indicated by the finding that in urchin eggs stratified by centrifugation NAADP-sensitive $\mathrm{Ca}^{2+}$ stores migrate to the opposite pole to CADPR- and IP ${ }_{3}$-sensitive stores (Lee and Aarhus 2000). Subsequently, NAADP-sensitive $\mathrm{Ca}^{2+}$ stores, but not $\mathrm{IP}_{3}$ - or CADPR-sensitive stores, were shown to be sensitive to disruption of the lysosomal proton gradient via blockers of the vacuolar $\mathrm{H}^{+}$ATPase such as bafilomycin $\mathrm{A} 1$, and to osmotic lysis of lysosomal stores by glycyl-L-phenylalanine-beta-naphthylamide (GPN), indicating that NAADP releases $\mathrm{Ca}^{2+}$ from lysosome-related acidic organelles (Churchill et al., 2002). NAADP-induced $\mathrm{Ca}^{2+}$ release was also found to be accompanied by an increase in lysosome luminal $\mathrm{pH}$ (Morgan and Galione 2007). Lysosome-related stores were subsequently confirmed as the target of NAADP in mammalian cells (Kinnear et al., 2004, Yamasaki et al., 2004). NAADP can trigger $\mathrm{Ca}^{2+}$ release from endosomes as well as lysosomes (Menteyne et al., 2006).

Despite this separation of stores, in some cell types NAADPevoked $\mathrm{Ca}^{2+}$ signalling has been shown to be abrogated by depletion of $E R \mathrm{Ca}^{2+}$ stores with thapsigargin or blocking of $\mathrm{IP}_{3} \mathrm{R}$ and/or RyR-mediated signalling (Cancela etal., 1999, Santella et al., 2000, Churchill and Galione 2001, Boittin et al., 2002). These findings have led to the 'NAADP trigger hypothesis', whereby $\mathrm{Ca}^{2+}$ released by the action of NAADP can recruit IP ${ }_{3} R$ and RyR-mediated signalling pathways via CICR (Churchill and Galione 2001). Differences in the extent of ER store involvement in different cell types is likely to be a consequence of different patterns of localisation of the stores and receptors, with recruitment occurring when NAADP-mediated $\mathrm{Ca}^{2+}$ release occurs in close proximity to ER channels (Kinnear et al., 2004, Kinnear et al., 2008, Morgan et al., 2011). NAADP can also potentiate $\mathrm{ER} \mathrm{Ca}^{2+}$ release by providing $\mathrm{Ca}^{2+}$ that is sequestered, thus increasing ER loading and sensitising RyRs and $\mathrm{IP}_{3} \mathrm{Rs}$ via their sensitivity to $\left[\mathrm{Ca}^{2+}\right]$ I (Morgan et al., 2011).

Conversely, recent findings indicate that $\mathrm{Ca}^{2+}$ released from the ER can activate the NAADP pathway, both by stimulating $\mathrm{Ca}^{2+}$ dependent NAADP synthesis and by activating NAADP-regulated $\mathrm{Ca}^{2+}$ channels (Morgan et al., 2013). This effect may be dependent on local microdomains of high $\left[\mathrm{Ca}^{2+}\right]$ i at junctions between the ER and acidic organelles. Such contact between the ER and acidic organelles has been identified both in sea urchin eggs (Morgan et al., 2013) and in human fibroblasts (Kilpatrick et al., 2013). Bidirectional communication between these different organelles may have functional relevance for endolysosomal function as well as for the generation of $\mathrm{Ca}^{2+}$ signals, with one model predicting that different arrangements of $\mathrm{Ca}^{2+}$ signalling proteins on the membranes of the two organelles might generate functionally heterogeneous $\mathrm{Ca}^{2+}$ microdomains (Penny et al., 2014).

\section{Two-pore channels as NAADP-regulated $\mathrm{Ca}^{2+}$ channels}

Based on the characteristics of NAADP-induced $\mathrm{Ca}^{2+}$ signalling described above, candidate NAADP-regulated $\mathrm{Ca}^{2+}$ channels would be expected to possess the following properties: ability to form a functional $\mathrm{Ca}^{2+}$ channel; localisation to the endolysosomal compartment; capacity to bind NAADP with all the characteristics displayed by the native NAADP receptor; sensitivity to pharmacological agents that inhibit NAADP-evoked $\mathrm{Ca}^{2+}$ signalling, e.g. $\mathrm{Ned}-19$, or to high concentrations of L-type $\mathrm{Ca}^{2+}$ blockers; and to be functionally inhibited by lysosomal disruption, e.g. with bafilomycin A1 or GPN (Galione et al., 2009). In addition, an NAADP-regulated $\mathrm{Ca}^{2+}$ channel should be insensitive to $\mathrm{IP}_{3} \mathrm{R}$ and RyR agonists and antagonists, and to ER store depletion by SERCA inhibitors; however, due to the 'trigger' effect of NAADP-evoked $\mathrm{Ca}^{2+}$ signalling seen in some cell types, an effect of these agents on the total response to NAADP might still be observed (Galione et al., 2009). Based on these criteria, TPCs (gene name Tpcn), members of the voltage-gated cation channel superfamily (Ishibashi et al., 2000), are currently the strongest candidates for being key components of NAADP-regulated $\mathrm{Ca}^{2+}$ channels (Brailoiu et al., 2009, Calcraft 
et al., 2009, Zong et al., 2009) (Fig. 2).

Humans and mice have two functional TPC isoforms, TPC1 and TPC2; a third isoform, TPC3, present in many vertebrates including rabbits and chickens (Ogunbayo et al., 2015), is the product of a pseudogene that does not encode a functional protein in humans, Old World monkeys, apes, mice or rats (Calcraft et al., 2009, Cai and Patel, 2010). Cai and Patel (2010) have characterised the evolutionary process that led to the degeneration of the TPC3 gene and loss of its protein's function in the primate lineage. TPC1 and TPC2 are widely expressed in mammalian tissues at the level of mRNA (Ishibashi et al., 2000, Brailoiu et al., 2009, Calcraft et al., 2009, Zong et al., 2009). Immunoblot and immunohistochemistry analysis have also shown that TPC1 protein is expressed at different levels in a variety of tissues in rodents (Ishibashi et al., 2000, Ruas et al., 2014). Subcellular localisation of exogenously expressed and endogenous TPCs has been studied. TPC2 is localised predominantly to late endosomes and lysosomes, while TPC1 exhibits a more general endolysosomal distribution in recycling endosomes, early and late endosomes, and lysosomes (Galione et al., 2011) (Fig. 1). Chicken TPC3 is localised to recycling endosomes and as yet unidentified organelles (Zhu et al., 2010). In human cytotoxic Tcells, endogenous TPCs have been shown in immunofluorescence studies to localise to the cytolytic granules, secretory vesicles that are exocytosed during the cell-killing response; moreover, TPCs play important functional roles in this response (Davis et al., 2012). In line with their localization to the endolysosomal compartment, TPCs have recently been shown to be involved in receptor trafficking and endolysosomal function (Grimm et al., 2014; Ruas et al., 2014). Deficiencies in endolysosomal trafficking in vivo have metabolic consequences. Thus TPC2 knockout mice are highly susceptible to hepatic cholesterol overload and liver damage consistent with non-alcoholic fatty liver hepatitis, likely due to abnormal hepatic cholesterol handling (Grimm et al., 2014). Also in line with a role for TPCs in endolysosomal function, infection of mouse cells by Ebola virus, which is taken up by macropinocytosis, followed by trafficking through endosomal vesicles, was inhibited by loss of TPC2 protein, suggesting that TPCs may be effective targets for anti-Ebola virus therapy (Sakurai et al., 2015).

As well as exhibiting the localisation to acidic stores expected of an endogenous NAADP receptor, TPCs also show the same specific pharmacology and sensitivity to NAADP as that demonstrated for an endogenous receptor. Thus, sensitivity to nanomolar NAADP is conveyed by expression of Homo sapiens (Hs) TPC1 in SKBR3 cells; this response is sensitive to bafilomycin A1 and ryanodine, suggesting coupling of lysosomal $\mathrm{Ca}^{2+}$ release to RyRs via CICR (Brailoiu et al., 2009). In HEK293 cells expressing recombinant HsTPC2, NAADP at nanomolar and low micromolar concentrations induces $\mathrm{Ca}^{2+}$ release at levels significantly above the endogenous response; this response is blocked by bafilomycin A1 and reduced by inhibition of RyRs, InsP ${ }_{3} R s$, or SERCA, again suggesting an extent of functional coupling of stores (Calcraft et al., 2009). Millimolar NAADP concentrations do not elicit such a response, and anti-TPC2 small hairpin RNAs (shRNAs) inhibit endogenous responses to activated NAADP (Davis et al., 2012). Similarly, endogenous NAADP-induced $\mathrm{Ca}^{2+}$ release in SKBR3 cells was inhibited by anti-TPC1 shRNAs (Brailoiu et al., 2009). In line with TPCs being related to voltage-gated $\mathrm{Ca}^{2+}(\mathrm{Cav})$ and $\mathrm{Na}^{+}$ channels (Nav), molecular docking studies of TPC1 suggested that the pore region of this protein has the potential to bind Cav and
Nav antagonists; such antagonists also inhibited NAADP-induced $\mathrm{Ca}^{2+}$ signals (Rahman et al., 2014).

Importantly for the status of TPCs as a credible candidate for the endogenous NAADP target channel, $\mathrm{Ca}^{2+}$ release in response to NAADP has been found to be abrogated in pancreatic $\beta$-cells from TPC2 KO mice (Calcraft et al., 2009). Investigation of HsTPC2 reconstituted in a lipid bilayer has indicated that the channel is activated by nanomolar and low micromolar NAADP, but inhibited by micromolar concentrations (Pitt et al., 2010). Binding of NAADP to TPC2 appears to occur at two sites, a high-affinity activating site and a low-affinity inhibitory site, as expected of an endogenous NAADP receptor (Rosen et al., 2009). Similar reconstitution of HsTPC1 in a lipid bilayer has allowed a biophysical comparison of the two isoforms. Using such an approach, Rybalchenko et al., (2012) showed that TPC1 functions as a NAADP-activated and voltage-, $\mathrm{pH}-$, and $\mathrm{Ca}^{2+}$-regulated channel. Activation of TPC1 by NAADP was shown to be dynamically regulated by the membrane potential. Another study of TPC1 reconstituted in a lipid bilayer confirmed that TPC1 activity is stimulated by NAADP, and showed that TPC1 and TPC2 differ in their ion selectivity and modulation by $\mathrm{Ca}^{2+}$ and $\mathrm{pH}$, with TPC1 being much more permeable to protons (Pitt et al., 2014). This has led to the suggestion that NAADP

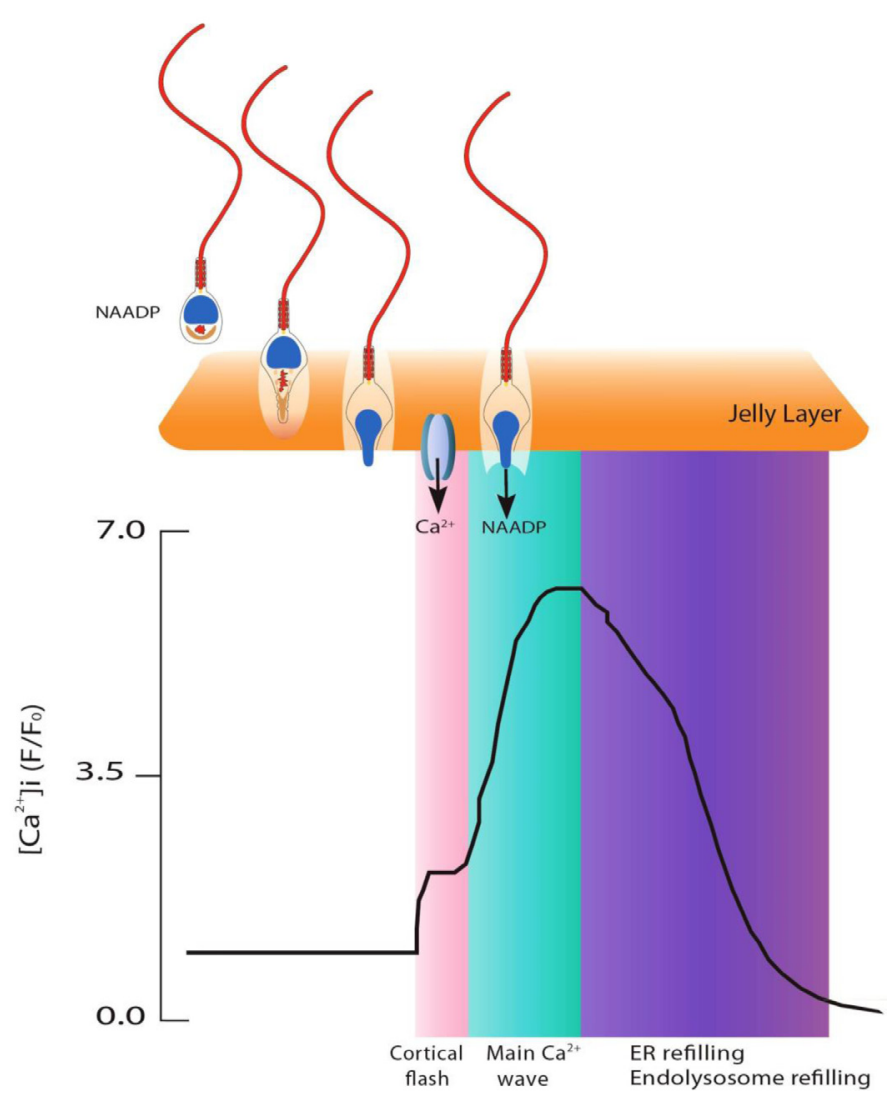

Fig. 2. Fertilization induces $\mathbf{C a}^{2+}$ release in sea urchin eggs. The fusion of a sea urchin sperm with the egg generates a transient, NAADP-induced cortical 'flash' of $\mathrm{Ca}^{2+}$ influx, marking the beginning of the egg activation process. The main $\mathrm{Ca}^{2+}$ wave at fertilization is due to $\mathrm{Ca}^{2+}$ release from the egg's internal stores in response to three $\mathrm{Ca}^{2+}$ mobilizing messengers - IP3, CADPR and NAADP. $\mathrm{Ca}^{2+}$ is taken back into the ER via SERCA, and by the endolysosomal vesicles via the calcium-proton exchanger (CHX). 
triggers $\mathrm{H}^{+}$release from lysosomes and endolysomes via TPC1, but that the $\mathrm{Ca}^{2+}$-releasing ability of TPC1 depends on the ionic composition of the acidic stores and might be influenced by other regulators that affect TPC1 ion permeation (Pitt et al., 2014).

As much of the early investigation of NAADP-mediated $\mathrm{Ca}^{2+}$ signalling was conducted in sea urchin egg systems, a study thoroughly characterising Strongylocentrotus purpuratus (Sp) TPCs provides important evidence for TPCs as an endogenous NAADP receptor (Ruas et al., 2010). In this study, NAADP binding was shown to be increased in sea urchin egg fractions containing high levels of endogenous SpTPCs. NAADP bound to immunoprecipitated SpTPCs with high specificity and nanomolar affinity. Binding was irreversible in high $\left[\mathrm{K}^{+}\right]$conditions, an established feature of NAADP binding to endogenous receptors in sea urchins but not in mammals (Dickinson and Patel2003). Finally, exogenous expression of SpTPC1 and SpTPC2 in HEK293 cells resulted in $\mathrm{Ca}^{2+}$ release in response to NAADP, in a manner sensitive to bafilomycin A1 and to desensitising concentrations of NAADP and Ned-19 (Ruas et al., 2010). Another study that expressed SpTPC1 and SpTPC2 in SKBR3 cells also showed that this led to enhanced NAADP-induced $\mathrm{Ca}^{2+}$ signalling, as did expression of SpTPC3 (Brailoiu et al., 2010). In contrast Ruas et al., (2010) found that expression of SpTPC3 in HEK293 cells not only did not lead to enhanced NAADP-induced $\mathrm{Ca}^{2+}$ signalling but it actually inhibited the endogenous NAADP response in this cell type. The reason for these discrepancies relating to SpTPC3's role in NAADP-induced $\mathrm{Ca}^{2+}$ release remains unclear. In summary, a compelling body of evidence suggests that TPCs are an endogenous target of NAADP.

Despite these many and varied findings in support of a link between TPCs and NAADP-mediated $\mathrm{Ca}^{2+}$ signalling, the claim that TPCs are NAADP-regulated $\mathrm{Ca}^{2+}$ channels has been challenged by a study by Wang et al.,2012), which showed that pancreatic $\beta$-cells from mice described as TPC1/TPC2 double knockouts still retained the ability to release $\mathrm{Ca}^{2+}$ in response to NAADP. The study also reported that electrophysiological analysis of TPCs in cells in which the lysosomes had been swollen with vacuolin showed that TPC1 and TPC2 were primarily $\mathrm{Na}^{+}$channels regulated by the lysosomal lipid phosphatidylinositol 3,5-bisphosphate $(\mathrm{PI}(3,5) \mathrm{P} 2)$. A further study by a related group confirmed the ability of TPCs to conduct $\mathrm{Na}^{+}$(Cang et al., 2013).

However, two recent studies have confirmed the link between TPCs and NAADP-mediated $\mathrm{Ca}^{2+}$ signalling. The first of these studies has shown that while recombinant TPC2 can conduct $\mathrm{Na}^{+}$in response to $\mathrm{PI}(3,5) \mathrm{P} 2$, it can also be activated by NAADP, leading to $\mathrm{Ca}^{2+}$ release from endolysosomal stores; the same study also identified $\mathrm{Mg}^{2+}$ and the mitogen-activated protein kinases (MAPKs) C-Jun N-terminal kinase (JNK) and P38 as novel regulators of TPC2 (Jha et al., 2014). The second study, by Ruas et al.,2015) reaffirmed the status of TPCs as NAADP-regulated $\mathrm{Ca}^{2+}$ channels with the first analysis of the biophysical properties of endogenous mammalian TPCs and investigation of the effects of eliminating TPC expression on NAADP-evoked $\mathrm{Ca}^{2+}$ signalling, in the only definitively demonstrated TPC knockout mouse cells studied to date. Importantly, this study of mouse embryonic fibroblasts (MEFs) derived from TPC1/2 double knockout (DKO) mice showed that NAADP-evoked $\mathrm{Ca}^{2+}$ signalling was lacking in the absence of TPCs. Moreover, NAADP-evoked $\mathrm{Ca}^{2+}$ signalling was restored in the DKO MEFs by expression of either mouse TPC1 or TPC2 recombinant protein, but not by expression of a TPC2 pore mutant or transient receptor potential cation channel, mucolipin subfamily, member 1 (TRPML1), another endolysosomal ion channel previously proposed as a candidate NAADP-regulated $\mathrm{Ca}^{2+}$ channel. In addition, truncated forms of mouse TPC1 and TPC2 proteins predicted to be expressed in the putative TPC1/2 DKO cells studied by Wang et al., (2012) were found to be functional, casting doubt on whether those cells had a true loss of TPC function. Importantly, the effects of endogenous TPC loss were not only assessed by single-cell $\mathrm{Ca}^{2+}$ imaging after addition of cell-permeant NAADP-AM to wild type (WT) and DKO MEFs, but also by electrophysiological analysis carried out by patch-clamping of single endolysosomes. This latter analysis confirmed that endogenous TPCs are directly able to conduct $\mathrm{Ca}^{2+}$ into and out of the endolysosomal compartment in response to NAADP (Ruas et al., 2015).

Despite multiple lines of evidence implicating TPCs as NAADPregulated $\mathrm{Ca}^{2+}$ channels, it still remains unclear how TPCs interact with NAADP. On the one hand immuno-affinity purification of endogenous sea urchin TPCs has shown that such purified TPCs are associated with the ability to bind NAADP with the same high affinity as the native urchin NAADP receptor (Ruas et al., 2010). However, other recent studies have suggested that NAADP may require an intermediary protein to regulate TPC-mediated $\mathrm{Ca}^{2+}$ release. Thus, studies employing ${ }^{[2} \mathrm{P}-5$-azido]NAADP as a photoaffinity probe have identified small molecular weight proteins that appear to be high-affinity NAADP-binding protein(s) that are unrelated to TPCs, in both mouse pancreas (Lin-Moshier et al., 2012) and sea urchin egg homogenates (Walseth et al., 2012). The sea urchin egg NAADP-binding protein(s) have been shown to be associated with immunoprecipitated TPCs, suggesting a physiological interaction between these proteins and TPCs. It has also been shown that the ability of urchin TPCs to bind NAADP is mediated by such an accessory protein (Walseth et al., 2012). Importantly, in the TPC DKO mice studied by Ruas et al., (2015) that had a demonstrated loss of expression of both TPC1 and TPC2, high-affinity NAADP binding was still present, in line with such binding being mediated by a protein other than a TPC. An urgent task now is to identify such an NAADP-binding protein at the molecular level, to characterise the nature of its interaction with TPCs, and to show how the interaction relates to the function of TPCs in vivo.

\section{Role of NAADP and TPCs during fertilization and embryogenesis}

The importance of $\mathrm{Ca}^{2+}$ signalling in embryonic development is well established (Berridge 2001). $\mathrm{Ca}^{2+}$ signals play important roles throughout embryogenesis, having been implicated in such key developmental stages as fertilization (Parrington etal., 2007, Wakai et al., 2011, Nomikos et al., 2012, Nader et al., 2013), control of cytokinesis (Webb etal., 1997), coordination of complex cell movements during gastrulation (Wallingford et al., 2001), formation of left-right asymmetry (Yoshiba and Hamada 2014), skeletal muscle formation (Cheung et al., 2011), and development of the nervous system (Leclerc et al., 2012). To date, most studies of NAADP and TPC function during embryogenesis have focused on their role as mediators of $\mathrm{Ca}^{2+}$ release during activation of the egg at fertilization. This reflects the fact that NAADP, like cADPR, was first identified as a $\mathrm{Ca}^{2+}$-release agent in sea urchin eggs, with the sea urchin egg homogenate having proved to be a very important system 


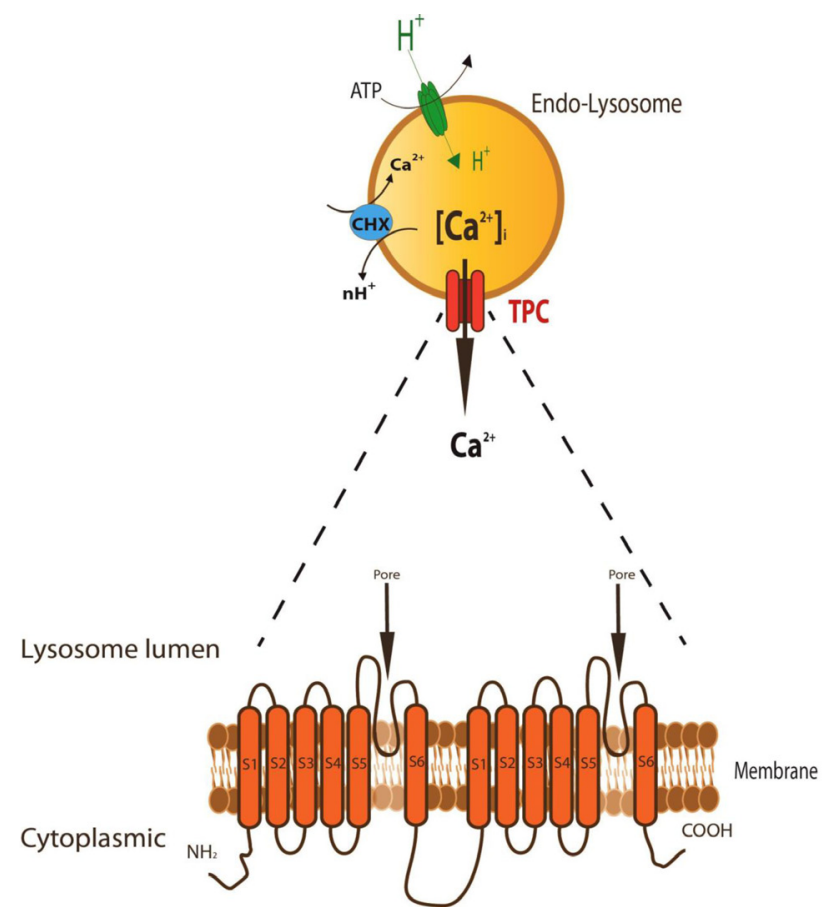

Fig. 3. Schematic drawing of endolysosomal membrane shows the localization of the transmembrane topology of the two-pore channels (TPCs). There are two putative pore-forming repeats. Each of these repeats contains six transmembrane segments and an intervening pore-loop.

for the study of the mechanism of action of these $\mathrm{Ca}^{2+}$-mobilising messengers (Lee 2003). NAADP has been shown to be involved in mediating the cortical flash that occurs at fertilization in sea urchins and starfish and contributing to the $\mathrm{Ca}^{2+}$ wave that activates the egg, leading to a block to polyspermy and the activation of embryogenesis (Santella et al., 2012) (Fig. 3). The first direct link between endogenous TPCs and NAADP-induced $\mathrm{Ca}^{2+}$ signalling was shown by the finding, mentioned above, that immuno-purified sea urchin TPCs are associated with high-affinity NAADP binding (Ruas et al., 2010). This study also showed that urchin TPCs are localised to the cortex of the egg, the site of NAADP-induced $\mathrm{Ca}^{2+}$ release during fertilization. Like mammalian TPC1 and TPC2, expression of urchin TPC1 and TPC2 in HEK cells led to greatly enhanced NAADP-induced $\mathrm{Ca}^{2+}$ release; however, surprisingly urchin TPC3 inhibited endogenous NAADP-induced $\mathrm{Ca}^{2+}$ release in HEK cells, suggesting that it can act in a dominant negative manner (Ruas et al., 2010). In contrast, however, another study in which a slightly different variant of urchin TPC3 was expressed in a different cell line did not observe such inhibitory properties for this TPC3, the expression of which was instead shown to enhance NAADP-induced $\mathrm{Ca}^{2+}$ release, similar to the urchin TPC1 and TPC2 also assessed in this study (Brailoiu et al., 2010). Interestingly, a recent study of rabbit and chicken TPC3 isoforms has found no evidence that either of these vertebrate TPC3 isoforms can act in a dominant negative manner, although expression of chicken TPC3 did not lead to enhanced NAADP-induced $\mathrm{Ca}^{2+}$ release, unlike expression of rabbit TPC3, which did (Ogunbayo et al., 2015).

Other recent studies have investigated the role of urchin ADPribosyl cyclases (ARCs), the enzymes that have been shown to have the capacity to generate both CADPR and NAADP in vitro, and are therefore believed to fulfil the same role in vivo although this remains to be fully confirmed. Cloning of an urchin ARC and analysis of its enzymatic activity after expression in Xenopus oocytes showed that it could carry out both the base-exchange and cyclization reactions that generate NAADP and CADPR respectively, even though it had a luminal expression in the ER in this expression system (Churamani et al., 2007). In another study endogenous urchin ARCs were shown to be localised within the cortical granules of the egg (i.e., the acidic exocytotic vesicles involved in the cortical reaction that occurs during egg activation), and such ARCs were shown to be optimally active at the same acidic $\mathrm{pH}$ (Davis et al., 2008). This intraorganellar localisation is the first to be demonstrated for an enzyme that generates an intracellular messenger active in the cytosolic compartment and poses the question of how ARC substrates might gain entry to, and ARC products leave, the organelle. At least for CADPR, the study showed that the substrate for CADPR synthesis, $\beta-N A D^{+}$, enters the acidic organelle through a $\beta-N A D^{+}$transporter, while cADPR exits the organelle through a separate CADPR transporter. The physiological importance of ARCs for egg activation was shown by the fact that inhibition of these transporters inhibited the fertilizationinduced $\mathrm{Ca}^{2+}$ wave (Davis et al., 2008).

To gain insights into the functional roles of endogenous TPCs and ARCs during not just fertilization but also further development of the echinoderm embryo, a recent study investigated the role of ARCs and TPCs during fertilization in the starfish (Ramos et al., 2014). In contrast to sea urchins, in which three ARC isoforms were identified (Churamani et al., 2007; Davis et al., 2008), the starfish was found to only have a single ARC isoform (Ramos et al., 2014). In addition, like the urchin which has three TPC isoforms (Brailoiu et al., 2010; Ruas et al., 2010), the same number of these were identified in starfish (Ramos et al., 2014). Immunolocalisation analysis showed that the TPCs and one ARC isoform were all localised to the cortical region. However, while all three TPCs were present in the cortical granules, as in the urchin, the starfish $A R C$ was not found in cortical granules but in a different, unknown set of vesicles closely apposed to the cortical granules (Ramos et al., 2014). Intriguingly, immunogold electron microscopy indicated that starfish TPCs were localised to internal membranes within the cortical granules, posing questions about how this pattern of localisation allows them to function as $\mathrm{Ca}^{2+}$ channels in this organelle. Assuming that other pumps, exchangers and channels are present in the cortical granule inner membranes, one possibility is that separation of membrane-bound compartments within the cortical granules allows coupling of electrochemical gradients (as happens in mitochondria) (Ramos et al., 2014).

To study the functional role of ARCs and TPCs during starfish fertilization and embryogenesis, morpholinos (MOs) have been used to inhibit their expression (Ramos et al., 2014). Knockdown of TPC2 and TPC3 was shown to lead to abnormalities in the formation/elevation of the fertilization envelope. This result is consistent with the suggestion that TPCs play a functional role in the cortical granules, which make a major contribution to the formation of this envelope. Although individual knockdown of TPCs or ARC did not result in changes in the shape, timing or amplitude of $\mathrm{Ca}^{2+}$ dynamics at fertilization, simultaneous knockdown of all three TPC isoforms did lead to substantial abnormalities in the fertilization $\mathrm{Ca}^{2+}$ wave, indicating a role for TPCs in this process. Demonstrating the importance of ARC and TPC function to embryogenesis in starfish, 
knockdown of TPC2, TPC3, or ARC, led to embryonic lethality at the gastrula stage; in contrast, knockdown of TPC1 did not have any effects upon embryonic development (Ramos et al., 2014).

In vertebrates, XenopusARC CD38, and also ARC activity, were shown to be developmentally regulated during embryogenesis of this species (Churamani et al., 2012). Moreover, this study also demonstrated the functional importance of this protein for embryogenesis, since chemical or molecular inhibition of CD38 abolished ARC activity and disrupted elongation of the anterior-posterior axis and differentiation of skeletal muscle, culminating in embryonic death (Churamani et al., 2012). Evidence for an important role for
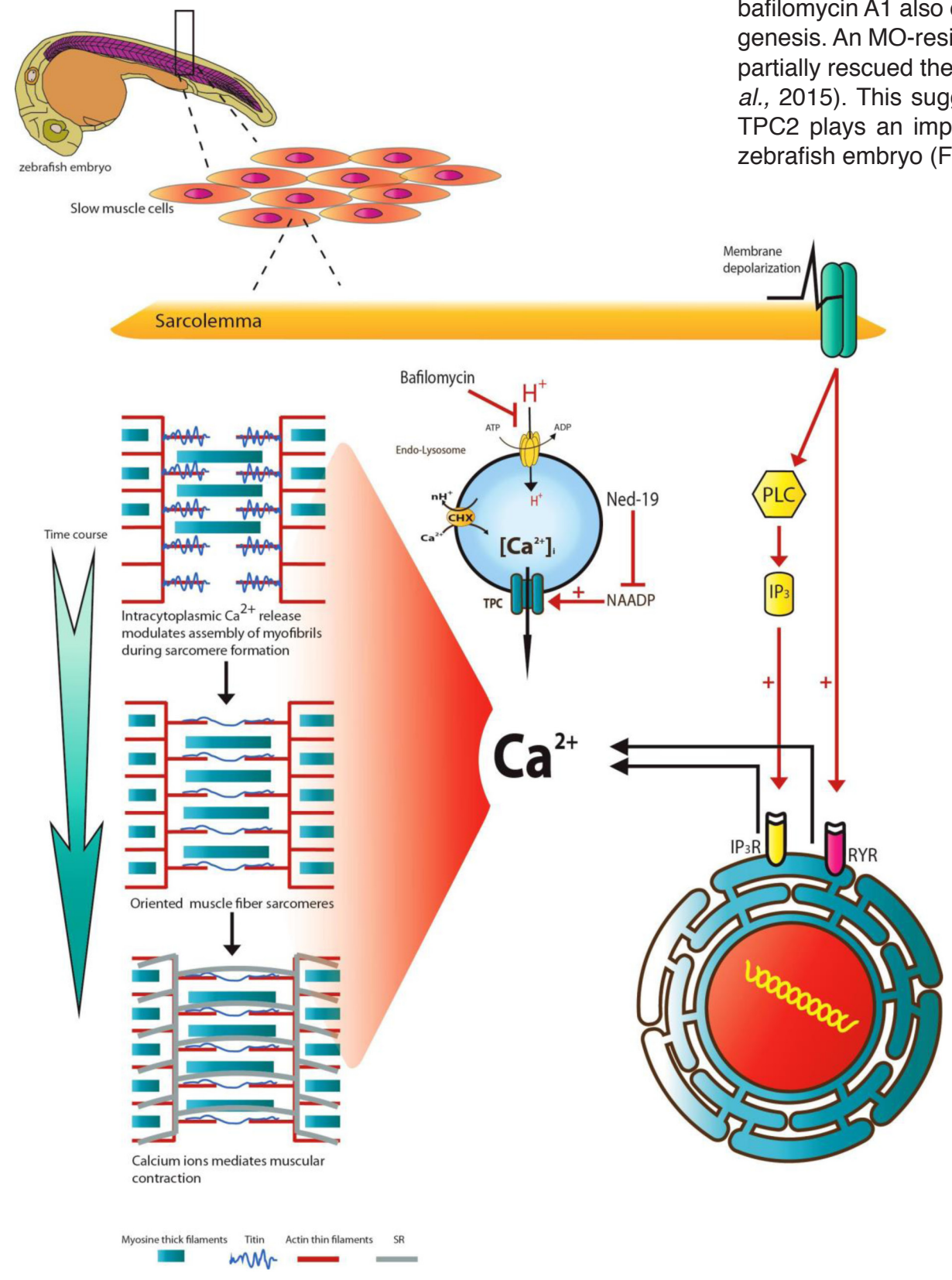

Fig. 4. Schematic diagram of the role of NAADP andTPCs during development of slow muscle cells (SMCs) in zebrafish embryos. Treatment with bafilomycin A1, Ned-19 or anti-TPC2 morphlinos disrupts $\mathrm{Ca}^{2+}$ signalling and myofibrilogenesis.
TPCs during embryonic development in vertebrates comes from a recent study that has investigated the role of TPC2 during development of slow muscle cells (SMCs) in the intact zebrafish embryo (Kelu et al., 2015). $\mathrm{Ca}^{2+}$ signals have previously been shown to accompany differentiation of SMCs during in vivo zebrafish development (Cheung et al., 2011). The recent study, in a transgenic zebrafish line that expresses the $\mathrm{Ca}^{2+}$-sensitive bioluminescent protein aequorin specifically in skeletal muscle cells, found that knockdown of TPC2 with MOs resulted in a dramatic attenuation of $\mathrm{Ca}^{2+}$ signals and a significant disruption of myofibrilogenesis (Kelu et al., 2015). Moreover, treatment of embryos with Ned19 , the specific antagonist of NAADP-induced $\mathrm{Ca}^{2+}$ release, or bafilomycin $\mathrm{A} 1$ also disrupted both $\mathrm{Ca}^{2+}$ signalling and myofibrilogenesis. An MO-resistant recombinant version of zebrafish TPC2 partially rescued the normal pattern of $\mathrm{SMC} \mathrm{Ca}{ }^{2+}$ signals (Kelu et al., 2015). This suggests that NAADP-induced $\mathrm{Ca}^{2+}$ release via TPC2 plays an important role during SMC development in the zebrafish embryo (Fig. 4). It will be important for future studies to investigate the mechanisms whereby such $\mathrm{Ca}^{2+}$ signals regulate muscle development in this manner.

Whether TPCs have functional roles during mammalian fertilization and embryonic development remains to be properly investigated. TPC single and double knockout mice are fertile and loss of TPC1 and TPC2 has no effect on embryonic viability or the ability to progress to adulthood (Calcraft et al., 2009, Ruas et al., 2014, Ruas et al., 2015). However given the capacity of mouse embryos to compensate for loss of expression of important $\mathrm{Ca}^{2+}$ signalling proteins by 'remodelling' other signalling pathways (Berridge et al., 2003), this does not exclude the possibility of important roles for TPCs during mammalian reproduction and embryogenesis. Indeed, a recent study that investigated the role of NAADP and TPCs in sperm biology found that NAADP could activate the acrosome reaction, whereas this response was blocked by treatment with Ned-19, as well as being absent in TPC1 knockout mice (Arndt et al., 2014). The study also found that NAADP binding sites and TPC1 showed co-localisation in the acrosomal region, providing further support for the idea that TPCs are NAADP-regulated $\mathrm{Ca}^{2+}$ channels. Interestingly, two narrow bellshaped dose-response curves were identified with maxima in either the nanomolar or low micromolar NAADP concentration range, with TPC1 being found to be responsible for activating the low affinity pathway by means of analysis of the TPC1 knockout (Arndt et al., 2014). This raises the question of whether the high affinity pathway involves TPC2, an issue that remains to be explored.

We still lack detailed information about the spatial and temporal expression of TPCs 
during mammalian embryonic development. However one study has investigated the expression of TPC1 and TPC2 in embryonic muscle during development and found that both isoforms are expressed in this tissue at embryonic stages E17 and E18 (Aley et al., 2010). Indeed, expression of both isoforms, but particularly of TPC2, was much more pronounced in the embryo than in the adult. Recent studies of TPC knockout mice have shown them to have abnormalities in smooth muscle contraction (Tugba Durlu-Kandilci etal., 2010), receptor trafficking and endolysosomal function (Ruas et al., 2014), storage and utilization of cholesterol by the liver (Grimm et al., 2014), angiogenesis (Favia et al., 2014), skeletal muscle function (Cang et al., 2013, Lin et al., 2014), brown adipose tissue thermogenesis (Lear et al., 2014) and heart contraction in response to $\beta$-adrenergic stimulation (Capel et al., 2015). Although these abnormalities may reflect defects in the signalling pathways regulating physiological responses in the affected tissues, it is also possible that they are due to disturbances of TPC expression during development. Since all of these studies are of whole-animal knockouts, it will be important in the future to generate inducible knockouts in which loss of TPC expression can be triggered at different stages of embryogenesis or development to adulthood. In addition, since the phenotype of a particular cell type or tissue in a whole animal knockout might not reflect the effects of a defect in TPC function in a different part of the organism, it will also be important in the generation of such inducible TPC knockouts to include those that are cell-type specific (conditional), so that the effects of loss of TPC expression in a specific cell type or tissue can be compared with loss of expression in the whole organism.

\section{Role of NAADP and TPCs during commitment and differentiation}

The processes of commitment and terminal differentiation are central to the formation of specialised cell types during embryogenesis and continue to be important during adulthood in repair and regeneration. A number of studies have highlighted the central role that $\mathrm{Ca}^{2+}$ signals play during specialisation of a variety of different cell types. The vast majority of these studies, however, have exclusively used in vitro models and have not distinguished between commitment (or, more properly, in vitro surrogate specification) and terminal differentiation. $\mathrm{Ca}^{2+}$ transients that occur in the first few days of multipotent neural crest cell specialisation have been shown to be required for neuronal differentiation in vitro (Carey and Matsumoto 1999). Skeletal muscle fibre differentiation also requires $\mathrm{Ca}^{2+}$ signals, with the spatiotemporal pattern being an important factor in fibre type specialisation; thus prolonged elevation of intracellular $\mathrm{Ca}^{2+}$-induces slow-twitch fibre differentiation, while short, high amplitude transients favour fast-twitch fibre formation (Chin et al., 1998). In B lymphocytes, $\mathrm{Ca}^{2+}$ signals initiate changes in gene expression and cellular events including apoptosis and differentiation (Baba and Kurosaki 2011). $\mathrm{Ca}^{2+}$ signals also appear to regulate many important aspects of keratinocyte differentiation, for instance the formation of desmosomes, adherens junctions and tight junctions, which maintain cell-cell adhesion, although, again, many of the data are derived from in vitro models (Bikle etal., 2012). Specialisation requires the expression of cell type-specific genes, and $\mathrm{Ca}^{2+}$ signals modulate this through regulation of transcription factors, such as cAMP response element binding protein (CREB) (Shaywitz and Greenberg 1999) and NF-AT (Hogan et al., 2003), and $\mathrm{Ca}^{2+}$ signal transducers, such as the protein phosphatase calcineurin and CaM-dependent protein kinases (CaMKs) (Shaywitz and Greenberg 1999, Ikura et al., 2002, Hogan et al., 2003). Thus, CaMK and calcineurin/NF-AT signalling have been shown to drive transcription of myogenin, a key regulator of myogenesis ( $\mathrm{Xu}$ et al., 2002, Armand et al., 2008), while disruption of intracellular $\mathrm{Ca}^{2+}$ signalling (Porter et al., 2002) or global in vivo NF-AT deletion (Kegley et al., 2001) inhibits muscle differentiation. The pattern of $\mathrm{Ca}^{2+}$ signals has been shown to be important in determining the response elicited in specialising cells - in neuron precursor cells, $\mathrm{Ca}^{2+}$ transients of a narrow range of frequencies affect phenotype development through modulation of neurotransmitter expression and channel maturation, while waves of elevated intracellular $\mathrm{Ca}^{2+}$ drive axon outgrowth (Gu and Spitzer 1995). In 3T3-L1 preadipocyte cells (Ntambi and Takova 1996) and primary adipose-derived human preadipocytes (Shi et al., 2000), increasing intracellular $\mathrm{Ca}^{2+}$ with an ionophore or thapsigargin within the first 24-48 hours of differentiation has been shown to inhibit adipogenesis, as judged by lipid accumulation and expression/activity of mature adipocyte markers. One caveat with such treatments is that they might also interfere with endogenous $\mathrm{Ca}^{2+}$ signalling by depleting stores and therefore mask highly specific signalling. The inhibition was still observed in the presence of a $\mathrm{Ca}^{2+}$ chelator (Ntambi and Takova 1996), suggesting that it was store depletion rather than increased intracellular $\mathrm{Ca}^{2+}$ that was having the effect. When intracellular $\mathrm{Ca}^{2+}$ levels were increased by such means during later differentiation, (i.e., between 48-72 hours after induction), the effect on adipogenesis was positive (Shi et al., 2000). This might indicate a role for $\mathrm{Ca}^{2+}$ in promoting terminal differentiation; however, it is again difficult to draw conclusions as the pharmacologically-induced $\mathrm{Ca}^{2+}$ rises are unlikely to mimic the spatiotemporal patterns of physiological signals that might be occurring during commitment and differentiation in vivo.

Recent studies have implicated NAADP- and TPC-mediated $\mathrm{Ca}^{2+}$ signalling in the specialisation of several cell types. Liposomemediated delivery of NAADP to PC12 cells, a model for neuronal differentiation, resulted in $\mathrm{Ca}^{2+}$ release and development of neuronal morphology (Brailoiu et al., 2006). Induction of differentiation was also triggered by cADPR-mediated, but not $\mathrm{IP}_{3}$-mediated, $\mathrm{Ca}^{2+}$ release (Brailoiu et al., 2006). Another study suggested that TPC2 plays a dual role during commitment/specification and differentiation of mouse embryonic stem cells (ESCs) into neurons; thus expression of TPC2 was markedly decreased during generation of neural progenitors, but gradually increased again during later stages of neural differentiation (Zhang et al., 2013). In line with such a dual role, knockdown of TPC2 accelerated ESC specification into neural progenitors but inhibited these from differentiating into neurons, while overexpression of TPC2 inhibited ESCs from becoming specified to the early neural lineage (Zhang et al., 2013).

As already mentioned, inhibition of the ARC CD38 during Xenopus embryogenesis inhibited muscle differentiation (Churamani et al., 2012). Membrane-permeant NAADP-acetoxymethyl ester (AM) has been shown to promote myogenic differentiation in primary skeletal muscle precursor cells and in the $\mathrm{C} 2 \mathrm{C} 12$ myogenic cell line, while inhibition of NAADP-induced $\mathrm{Ca}^{2+}$ release with $\mathrm{Ned}-19$, bafilomycin A1 or desensitising NAADP concentrations inhibits differentiation, as assessed by morphological and molecular markers (Aley et al., 2010). While TPC1 mRNA expression was found to be relatively constant throughout the course of myocyte 
terminal differentiation in these systems, TPC2 mRNA expression was highest in the first few days of differentiation and substantially reduced thereafter, indicating the possibility of distinct roles for the two isoforms during the process. siRNA-mediated knockdown of TPC1 in C2C12 cells caused moderate impairment of differentiation, while TPC2 knockdown caused substantial inhibition (Aley et al., 2010). Recently, TPC2 has also been implicated in osteoclast differentiation (Notomi et al., 2012). Expression of TPC2 mRNA was upregulated in primary bone marrow stromal cells (measured after 5 days of differentiation) and an osteoclast precursor cell line (measured after 3 days of differentiation) when osteoclastogenesis was induced; moreover, miRNA-mediated TPC2 knockdown disrupted $\mathrm{Ca}^{2+}$ signalling and inhibited differentiation. These effects could be mediated by NF-AT, as TPC2 knockdown has been shown to dramatically inhibit nuclear translocation of this transcription factor (Notomi et al., 2012). Another recent study has found that extracellular application of NAADP affects osteoclast formation, demonstrating a potential role for NAADP-induced $\mathrm{Ca}^{2+}$ signalling in this process (Cheng et al., 2015). Most recently, extracellularly applied NAADP also stimulated differentiation of human epidermal keratinocytes into terminally differentiated cells, as assessed by an increase in mRNA transcripts associated with keratinocyte differentiation (Park et al., 2015). Such extracellular NAADP treatment also enhanced the migration and proliferation of human epidermal keratinocytes in an in vitro wound scratch assay, and wound closure in an in vivo mouse model (Park et al., 2015).

NAADP is thought to be generated in vivo by the ADP-ribosyl cyclase CD38 (Cosker et al., 2010), which also generates cADPR (Lee 2012). CD38 has been implicated in differentiation of osteoclasts (Sun et al., 2003) and hematopoietic cells (Orciani et al., 2008). CD38 has been shown to be present in the nucleus (Adebanjo et al., 1999) and NAADP has been shown to trigger nuclear $\mathrm{Ca}^{2+}$ signals in pancreatic acinar cells (Gerasimenko et al., 2003), while depolarization of Aplysia neurons triggers the translocation of CD38 to the nucleus (Bezin et al., 2008). Nuclear $\mathrm{Ca}^{2+}$ signals play a role in the differentiation of cardiomyocytes (Janowski et al., 2006), and retinoic acid-induced differentiation of HL-60 myeloblastic cells is associated with the appearance of active CD38 in the nucleus (Yalcintepe et al., 2005). In future studies, therefore, it will be important to characterise mechanistically the links between NAADP- and TPC-mediated $\mathrm{Ca}^{2+}$ release and nuclear $\mathrm{Ca}^{2+}$ signals, as well as to ascertain the role of the latter in the regulation of commitment and/or differentiation.

\section{Role of NAADP and TPCs in autophagy}

Autophagy is an evolutionarily-conserved catabolic degradation process utilised by eukaryotic cells and tissues in response to environmental stresses such as starvation and disease (Sandri 2010, Choi et al., 2013) and it also plays important roles in development and differentiation (Mizushima and Komatsu 2011, Zois et al., 2011, Murrow and Debnath 2013). The fact that autophagy involves degradation by the autolysosome, which is formed by fusion of an autophagasome and a lysosome, suggests that NAADP signalling and TPCs might be involved in this process. In line with this, introduction of NAADP into rat astrocytes not only induces $\mathrm{Ca}^{2+}$ signals from acidic organelles in these cells, but also increases levels of the autophagic markers LC3II and beclin-1 (Pereira et al., 2011). The NAADP-induced increases in LC3II levels were reduced in cells expressing a dominant-negative TPC2 construct. NAADP-induced $\mathrm{Ca}^{2+}$ signalling mediated by TPC2 may either regulate autophagy by triggering subsequent $\mathrm{ER} \mathrm{Ca}{ }^{2+}$ release which then activates $\mathrm{Ca}^{2+} /$ calmodulin-dependent kinase- $\beta$ and $\mathrm{AMP}$-activated protein kinase, or by local $\mathrm{Ca}^{2+}$ release events that promote fusion of autophagosomes and lysosomes (Pereira et al., 2011).

In another study, overexpression of TPC2 in HeLa or mouse ES cells inhibits autophagosomal-lysosomal fusion, thereby resulting in the accumulation of autophagosomes ( $\mathrm{Lu}$ et al., 2013). Knockdown of TPC2 or treatment of cells with the NAADP antagonist Ned-19 also markedly decreases the accumulation of autophagosomes (Lu et al., 2013). In two other studies, regulation of autophagic flux by dynein-mediated autophagosomes has been shown to be inhibited by Ned-19 (Xu et al., 2013, 2014). Mice lacking CD38 (the enzyme that can generate cADPR and NAADP) also show defects in autophagosome trafficking and consequently impaired autophagic flux in coronary arterial myocytes (Xiong et al., 2013, Zhang et al., 2014).

Presenilins are required for efficient proteolysis in autophagy, a failure in this mechanism being linked to the pathogenesis of several major neurodegenerative diseases, particularly Alzheimer's disease (Nixon and Yang, 2011). Absence of presenilin expression has been shown to be associated with abnormalities in lysosomal $\mathrm{Ca}^{2+}$, as well as changes in TPC expression and level of dimerization, which might be factors in the disruption of autophagy in presenilin-null cells (Neely Kayala et al., 2012). TPC2 has also been shown to interact physically with $\mathrm{Hax}-1$, a negative regulator of autophagy and apoptosis (Lam et al., 2013). Most recently, a study of skeletal muscle in TPC2 knockout mice has shown that they have abnormal autophagic flux in their skeletal muscle. Thus muscle derived from such mice shows exacerbated autophagy during starvation (Lin et al., 2014). This study also showed that TPC2 is associated with the nutrient sensor, mammalian target of rapamycin (mTOR), in skeletal muscle, suggesting that TPC2 may modulate mTOR reactivation during autophagy and therefore contribute to muscle homeostasis. An association between human TPCs and mTOR was identified by a recent study of the TPC 'interactome' (Lin-Moshier et al., 2014). Another recent study also identified an important role for TPCs in muscle function linked to its association with mTOR (Cang et al., 2013). In line with this, the study reported that mice characterised as TPC1/2 DKO animals did not have gross differences in autophagy, but they did have severely reduced endurance after fasting. One caveat with this study was that the mice studied were the same animals investigated by Wang et al., (2012), whose DKO status has recently been questioned by Ruas et al., (2015). In particular, and as already discussed, the truncated TPC1 and TPC2 forms predicted to be expressed in those mice may in fact be partially or wholly functional (Ruas et al., 2015). Nevertheless, the study suggests that interfering with TPC expression does have significant effects upon muscle function during nutrient deprivation, and thus provides further evidence of a role for TPCs in nutrient sensing.

\section{Role of NAADP and TPCs in cancer}

The association between growth, differentiation and cancer is well known. Development of the embryo from a fertilized egg 


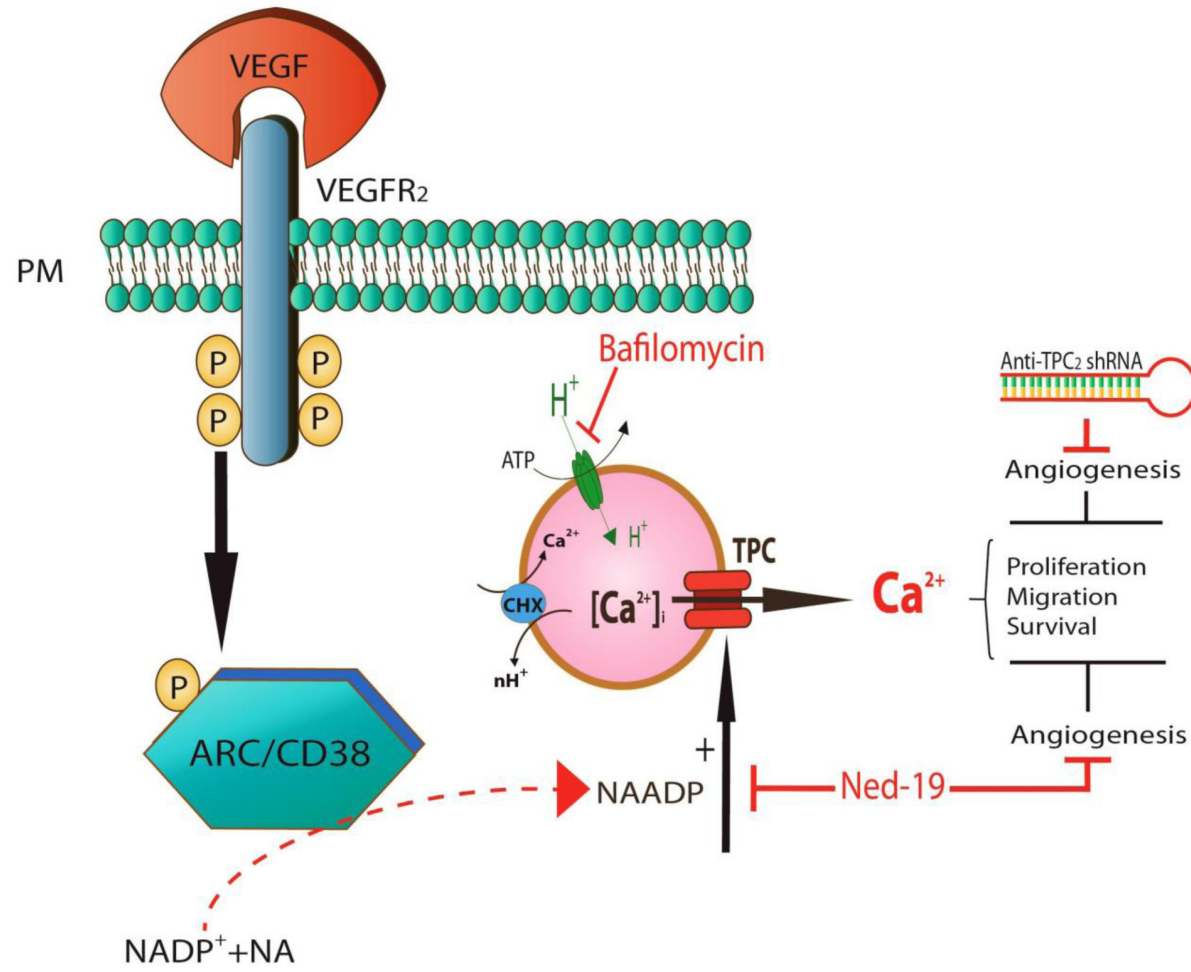

Fig. 5. Schematic representation of the role of NAADP-regulated $\mathrm{Ca}^{2+}$ signalling in VEGFmediated angiogenesis. Treatment with Ned-19, anti-TPC2 shRNAs, or TPC2 gene knockout abolishes VEGF-induced angiogenic responses.

to a multicellular organism of many different cell types results from the precise regulation of growth and differentiation, as does repair and regeneration of tissues and organs in the adult. It is not surprising then that abnormalities in the signalling pathways controlling these processes can lead to a cancerous phenotype (Berridge et al., 2003). The reported links between NAADP and TPCs and the control of growth and differentiation therefore raise the question of whether abnormalities in NAADP-regulated $\mathrm{Ca}^{2+}$ signalling and TPC action can lead to cancer. Exploration of this issue is still in its infancy; however a number of studies have begun to identify potential links between TPC2 and cancer. Thus, two studies of genetic factors underlying the development of growth and metastasis in oral squamous cell carcinoma in humans have identified over-expression of the TPC2 gene as a potential driver of the amplification of a genomic region, 11q13, observed in different tumours (Huang et al., 2006, Sugahara et al., 2011). What remains to be identified is the mechanism whereby overexpression of a lysosomal ion channel such as TPC2 could lead to changes in growth or metastatic potential of such tumours.

An association between TPC2 and cancer has also emerged from studies investigating the link between genes involved in skin pigmentation and a tendency for malignant melanoma. A number of such studies have identified polymorphisms in the TPC2 gene as potential risk factors for this condition (Pho and Leachman 2010, Kosiniak-Kamysz et al., 2014). Here, there is a clearer mechanistic rationale for TPC2 involvement, since the melanosome that secretes skin and hair pigment is a modified lysosome (Sturm 2009). Indeed, polymorphisms in the TPC2 gene have been shown to be associated with skin and hair colour in humans (Sturm 2009). It is possible then that changes in TPC2 expression or function lead to abnormalities in melanocyte biology that might potentiate tumorigenesis in this cell type.

In addition to these potentially direct links between TPC2 and cancer, a recent study has identified an important role for NAADP-regulated $\mathrm{Ca}^{2+}$ signalling and TPC2 during angiogenesis (Favia et al., 2014). This process, whereby new blood vessels form from pre-existing vessels, is a normal and crucial aspect of embryonic development, and plays an important role in wound healing in the adult. However, angiogenesis is also a fundamental step in the transition of tumours from a benign to a malignant state. Vascular endothelial growth factor (VEGF) and its receptors VEGFR1 and VEGFR2 play major roles in controlling angiogenesis, including vascularization of solid tumours. The role of NAADP-regulated $\mathrm{Ca}^{2+}$ signalling in VEGF-mediated angiogenesis has now been demonstrated by the finding that treatment with Ned-19 or anti-TPC2 shRNA abolishes VEGF-induced $\mathrm{Ca}^{2+}$ release and in vitro angiogenic responses in human umbilical vein endothelial cells (HUVECs) (Favia et al., 2014). In vivo, moreover, VEGF-induced vessel formation in matrigel plugs was abolished by Ned-19 and failed to occur in TPC2 knockout, but not in TPC1 knockout, mice (Favia et al., 2014). These findings suggest that pharmacological modulation of NAADP-induced $\mathrm{Ca}^{2+}$ signals mediated by TPC2 might represent an important future anti-cancer therapeutic strategy (Fig. 5).

\section{Concluding remarks}

Recent studies have highlighted the importance of $\mathrm{Ca}^{2+}$ signals regulated by NAADP acting on acidic endolysosomal organelles as important mediators of cellular function. Numerous studies over recent years have implicated TPCs, a family of endolysosomal proteins, as NAADP-regulated $\mathrm{Ca}^{2+}$ channels. In particular, a recent study has investigated the biophysical properties of endogenous mammalian TPCs, in the only definitively demonstrated TPC knockout mouse cells studied to date, and reaffirmed the status of TPCs as NAADP-regulated $\mathrm{Ca}^{2+}$ channels. $\mathrm{Ca}^{2+}$ signals have been shown to play important roles during numerous stages of embryogenesis, and in the differentiation of several key cell types. However, much remains to be established about the exact signalling mechanisms involved at different developmental stages. Analysis of the role of NAADP and TPCs in development and differentiation is still in its infancy, but recent studies suggest that they are important in embryonic development in echinoderms and as mediators of differentiation in neurons, skeletal muscle cells and osteoclasts in vertebrates. NAADP-induced $\mathrm{Ca}^{2+}$ signals and TPCs have also been implicated in autophagy, a process implicated in differentiation. Finally, recent studies have identified links between TPC2 and cancer, and shown that TPC2 plays a role in angiogenesis, a 
key developmental process that becomes subverted during tumour survival and metastasis. Further studies will be required to identify the precise mechanisms of TPC action and their links with NAADP signalling, and to relate these to the roles of TPCs in development, differentiation and other key processes in the cell and organism.

\section{References}

ADEBANJO, O. A., ANANDATHEERTHAVARADA, H. K., KOVAL, A. P., MOONGA, B. S., BISWAS, G., SUN, L., SODAM, B. R., BEVIS, P. J., HUANG, C. L., EPSTEIN, S., LAI, F. A., AVADHANI, N. G. and ZAIDI, M. (1999). A new function for CD38/ADP-ribosyl cyclase in nuclear $\mathrm{Ca}^{2+}$ homeostasis. Nat Cell Biol 1: 409-414.

ALEY, P. K., MIKOLAJCZYK, A. M., MUNZ, B., CHURCHILL, G. C., GALIONE, A. and BERGER, F. (2010). Nicotinic acid adenine dinucleotide phosphate regulates skeletal muscle differentiation via action at two-pore channels. Proc Natl Acad Sci U S A 107: 19927-19932.

ARMAND, A. S., BOURAJJAJ, M., MARTINEZ-MARTINEZ, S., ELAZZOUZI, H., DA COSTA MARTINS, P. A., HATZIS, P., SEIDLER, T., REDONDO, J. M. and DE WINDT, L. J. (2008). Cooperative synergy between NFAT and MyoD regulates myogenin expression and myogenesis. J Biol Chem 283: 29004-29010.

ARNDT, L., CASTONGUAY, J., ARLT, E., MEYER, D., HASSAN, S., BORTH, H., ZIERLER, S., WENNEMUTH, G., BREIT, A., BIEL, M., WAHL-SCHOTT, C., GUDERMANN, T., KLUGBAUER, N. and BOEKHOFF, I. (2014). NAADP and the two-pore channel protein 1 participate in the acrosome reaction in mammalian spermatozoa. Mol Biol Cell 25: 948-964.

BABA, Y. and KUROSAKI, T. (2011). Impact of $\mathrm{Ca}^{2+}$ signaling on B cell function. Trends Immunol 32: 589-594.

BERRIDGE, M. J. (2001). The versatility and complexity of calcium signalling. Novartis Found Symp 239: 52-64; discussion 64-57, 150-159.

BERRIDGE, M. J., BOOTMAN, M. D. and RODERICK, H. L. (2003). Calcium signalling: dynamics, homeostasis and remodelling. Nat Rev Mol Cell Biol 4: 517-529.

BEZIN, S., CHARPENTIER, G., LEE, H. C., BAUX, G., FOSSIER, P. and CANCELA, J. M. (2008). Regulation of nuclear $\mathrm{Ca}^{2+}$ signaling by translocation of the $\mathrm{Ca}^{2+}$ messenger synthesizing enzyme ADP-ribosyl cyclase during neuronal depolarization. J Biol Chem 283: 27859-27870.

BIKLE, D. D., XIE, Z. and TU, C. L. (2012). Calcium regulation of keratinocyte differentiation. Expert Rev Endocrinol Metab 7: 461-472.

BLUMENTHAL, S. A. (2012). Earl Sutherland (1915-1975) and the discovery of cyclic AMP. Perspect Biol Med 55: 236-249.

BOITTIN, F. X., GALIONE, A. and EVANS, A. M. (2002). Nicotinic acid adenine dinucleotide phosphate mediates $\mathrm{Ca}^{2+}$ signals and contraction in arterial smooth muscle via a two-pool mechanism. Circ Res 91: 1168-1175.

BRAILOIU, E., CHURAMANI, D., CAI, X., SCHRLAU, M. G., BRAILOIU, G. C., GAO, X., HOOPER, R., BOULWARE, M. J., DUN, N. J., MARCHANT, J. S. and PATEL, S. (2009). Essential requirement for two-pore channel 1 in NAADP-mediated calcium signaling. J Cell Biol 186: 201-209.

BRAILOIU, E., CHURAMANI, D., PANDEY, V., BRAILOIU, G. C., TULUC, F., PATEL, S. and DUN, N. J. (2006). Messenger-specific role for nicotinic acid adenine dinucleotide phosphate in neuronal differentiation. J Biol Chem 281: 15923-15928.

BRAILOIU, E., HOOPER, R., CAI, X., BRAILOIU, G. C., KEEBLER, M. V., DUN, N. J., MARCHANT, J. S. and PATEL, S. (2010). An ancestral deuterostome family of two-pore channels mediates nicotinic acid adenine dinucleotide phosphatedependent calcium release from acidic organelles. J Biol Chem 285: 2897-2901.

CAI, X. and PATEL, S. (2010) Degeneration of an intracellular ion channel in the primate lineage by relaxation of selective constraints. Mol Biol Evol27:2352-2359.

CALCRAFT, P. J., RUAS, M., PAN, Z., CHENG, X., ARREDOUANI, A., HAO, X., TANG, J., RIETDORF, K., TEBOUL, L., CHUANG, K. T., LIN, P., XIAO, R., WANG, C., ZHU, Y., LIN, Y., WYATT, C. N., PARRINGTON, J., MA, J., EVANS, A. M., GALIONE, A. and ZHU, M. X. (2009). NAADP mobilizes calcium from acidic organelles through two-pore channels. Nature 459: 596-600.

CANCELA, J. M., CHURCHILL, G. C. and GALIONE, A. (1999). Coordination of agonist-induced $\mathrm{Ca}^{2+}$-signalling patterns by NAADP in pancreatic acinar cells. Nature 398: 74-76.

CANG, C., ZHOU, Y., NAVARRO, B., SEO, Y. J., ARANDA, K., SHI, L., BATTAGLIAHSU, S., NISSIM, I., CLAPHAM, D. E. and REN, D. (2013). mTOR regulates lysosomal ATP-sensitive two-pore $\mathrm{Na}^{+}$channels to adapt to metabolic state. Cell 152: $778-790$

CAPEL RA, BOLTON EL, LIN WK, ASTON D, WANG Y, LIU W, WANG X, BURTON RB, BLOOR-YOUNG D, SHADE KT, RUAS M, PARRINGTON J, CHURCHILL GC, LEI M, GALIONE A, TERRAR DA. (2015). Two pore channels (TPC2s) and nicotinic acid adenine dinucleotide phosphate (NAADP) at lysosomal-sarcoplasmic reticular junctions contribute to acute and chronic $\beta$-adrenoceptor signaling in the heart. J Biol Chem. (doi: 10.1074/jbc.M115.684076).

CARAFOLI, E., SANTELLA, L., BRANCA, D. and BRINI, M. (2001). Generation, control, and processing of cellular calcium signals. Crit Rev Biochem Mol Biol36: 107-260.

CAREY, M. B. and MATSUMOTO, S. G. (1999). Spontaneous calcium transients are required for neuronal differentiation of murine neural crest. Dev Biol215: 298-313.

CHENG, X., HOOKWAY, E. S., KASHIMA, T., OPPERMANN, U., GALIONE, A. and ATHANASOU, N. A. (2015). The role of calcium and nicotinic acid adenine dinucleotide phosphate (NAADP) in human osteoclast formation and resorption. Calcif Tissue Int 96: 73-79.

CHEUNG, C.Y., WEBB, S.E., LOVE, D.L. and MILLER, A.L. (2011). Visualization, characterization and modulation of $\mathrm{Ca}^{2+}$ signaling during the development of slow muscle cells in intact zebrafish embryos. Int J Dev Biol 55:153-174.

CHIN, E. R., OLSON, E. N., RICHARDSON, J. A., YANG, Q., HUMPHRIES, C., SHELTON, J. M., WU, H., ZHU, W., BASSEL-DUBY, R. and WILLIAMS, R. S. (1998). A calcineurin-dependent transcriptional pathway controls skeletal muscle fiber type. Genes Dev 12: 2499-2509.

CHINI, E. N., BEERS, K. W. and DOUSA, T. P. (1995). Nicotinate adenine dinucleotide phosphate (NAADP) triggers a specific calcium release system in sea urchin eggs. J Biol Chem 270: 3216-3223.

CHINI, E. N. and DOUSA, T. P. (1996). Nicotinate-adenine dinucleotide phosphateinduced $\mathrm{Ca}^{2+}$-release does not behave as a $\mathrm{Ca}^{2+}$-induced $\mathrm{Ca}^{2+}$-release system. Biochem J 316: 709-711.

CHOI, A. M., RYTER, S. W. and LEVINE, B. (2013). Autophagy in human health and disease. N Engl J Med 368: 1845-1846.

CHOI, E., CHA, M. J. and HWANG, K. C. (2014). Roles of calcium regulating microRNAs in cardiac ischemia-reperfusion injury. Cells 3: 899-913

CHRISTENSEN, K. A., MYERS, J. T. and SWANSON, J. A. (2002). pH-dependent regulation of lysosomal calcium in macrophages. J Cell Sci 115: 599-607.

CHURAMANI, D., BOULWARE, M. J., GEACH, T. J., MARTIN, A. C., MOY, G. W., SU, Y. H., VACQUIER, V. D., MARCHANT, J. S., DALE, L. and PATEL, S. (2007) Molecular characterization of a novel intracellular ADP-ribosyl cyclase. PLOS One 2: e797.

CHURAMANI, D., GEACH, T. J., RAMAKRISHNAN, L., PRIDEAUX N., PATEL, S and DALE, L. (2012) The signaling protein CD38 is essential for early embryonic development. J Biol Chem 287: 6974-8.

CHURCHILL, G. C. and GALIONE, A. (2001). NAADP induces $\mathrm{Ca}^{2+}$ oscillations via a two-pool mechanism by priming $\mathrm{IP}_{3}$ - and cADPR-sensitive $\mathrm{Ca}^{2+}$ stores. $E M B O$ J 20: 2666-2671.

CHURCHILL, G. C., OKADA, Y., THOMAS, J. M., GENAZZANI, A. A., PATEL, S. and GALIONE, A. (2002). NAADP mobilizes $\mathrm{Ca}^{2+}$ from reserve granules, lysosomerelated organelles, in sea urchin eggs. Cell 111: 703-708.

CLAPHAM, D. E. (2007). Calcium signaling. Cell 131: 1047-1058.

COSKER, F., CHEVIRON, N., YAMASAKI, M., MENTEYNE, A., LUND, F. E., MOUTIN, M. J., GALIONE, A. and CANCELA, J. M. (2010). The ecto-enzyme CD38 is a nicotinic acid adenine dinucleotide phosphate (NAADP) synthase that couples receptor activation to $\mathrm{Ca}^{2+}$ mobilization from lysosomes in pancreatic acinar cells. J Biol Chem 285: 38251-38259.

COULTRAP, S. J. and BAYER, K. U. (2012). CaMKII regulation in information processing and storage. Trends Neurosci 35: 607-618.

DAVIS, L. C., MORGAN, A. J., CHEN, J. L., SNEAD, C. M., BLOOR-YOUNG, D. SHENDEROV, E., STANTON-HUMPHREYS, M. N., CONWAY, S. J., CHURCHILL, G. C., PARRINGTON, J., CERUNDOLO, V. and GALIONE, A. (2012). NAADP activates two-pore channels on $T$ cell cytolytic granules to stimulate exocytosis and killing. Curr Biol 22: 2331-2337.

DAVIS, L. C., MORGAN, A. J., RUAS, M., WONG, J. L., GRAEFF, R. M., POUSTKA A. J., LEE, H. C., WESSEL, G. M., PARRINGTON, J. and GALIONE, A. (2008). $\mathrm{Ca}^{2+}$ signaling occurs via second messenger release from intraorganelle synthesis sites. Curr Biol 18: 1612-1618.

DE KONINCK, P. and SCHULMAN, H. (1998). Sensitivity of CaM kinase II to the 
frequency of $\mathrm{Ca}^{2+}$ oscillations. Science 279: 227-230.

DE PRETIS, S. and PELIZZOLA, M. (2014). Computational and experimental methods to decipher the epigenetic code. Front Genet 5: 335

DICKINSON, G. D. and PATEL, S. (2003). Modulation of NAADP (nicotinic acidadenine dinucleotide phosphate) receptors by $\mathrm{K}^{+}$ions: Evidence for multiple NAADP receptor conformations. Biochem J 375: 805-812.

DOLMETSCH, R. E., LEWIS, R. S., GOODNOW, C. C. and HEALY, J. I. (1997). Differential activation of transcription factors induced by $\mathrm{Ca}^{2+}$ response amplitude and duration. Nature 386: 855-858.

FAVIA, A., DESIDERI, M., GAMBARA, G., D'ALESSIO, A., RUAS, M., ESPOSITO, B., DEL BUFALO, D., PARRINGTON, J., ZIPARO, E., PALOMBI, F., GALIONE, A. and FILIPPINI, A. (2014). VEGF-induced neoangiogenesis is mediated by NAADP and two-pore channel-2-dependent $\mathrm{Ca}^{2+}$ signaling. Proc Natl Acad $\mathrm{Scl}$ U S A 111: E4706-4715.

FESKE, S. (2007). Calcium signalling in lymphocyte activation and disease. Nat Rev Immunol 7: 690-702.

GALIONE, A., EVANS, A. M., MA, J., PARRINGTON, J., ARREDOUANI, A., CHENG, X. and ZHU, M. X. (2009). The acid test: the discovery of two-pore channels (TPCs) as NAADP-gated endolysosomal $\mathrm{Ca}^{2+}$ release channels. Pflugers Arch 458: 869-876

GALIONE, A., PARRINGTON, J. and FUNNELL, T. (2011). Physiological roles of NAADP-mediated $\mathrm{Ca}^{2+}$ signaling. Sci China Life Sci 54: 725-732.

GENAZZANI, A. A., EMPSON, R. M. and GALIONE, A. (1996). Unique inactivation properties of NAADP-sensitive $\mathrm{Ca}^{2+}$ release. J Biol Chem 271: 11599-11602.

GERASIMENKO, J. V., TEPIKIN, A. V., PETERSEN, O. H. and GERASIMENKO, O. V. (1998). Calcium uptake via endocytosis with rapid release from acidifying endosomes. Curr Biol 8: 1335-8.

GERASIMENKO, J. V., MARUYAMA, Y., YANO, K., DOLMAN, N. J., TEPIKIN, A. V., PETERSEN, O. H. and GERASIMENKO, O. V. (2003). NAADP mobilizes $\mathrm{Ca}^{2+}$ from a thapsigargin-sensitive store in the nuclear envelope by activating ryanodine receptors. J Cell Biol 163: 271-282.

GIFFORD, J. L., WALSH, M. P. and VOGEL, H. J. (2007). Structures and metal-ionbinding properties of the $\mathrm{Ca}^{2+}$-binding helix-loop-helix EF-hand motifs. Biochem J 405: 199-221.

GRIMM, C., HOLDT, L. M., CHEN, C. C., HASSAN, S., MULLER, C., JORS, S., CUNY, H., KISSING, S., SCHRODER, B., BUTZ, E., NORTHOFF, B., CASTONGUAY, J., LUBER, C. A., MOSER, M., SPAHN, S., LULLMANN-RAUCH, R., FENDEL, C., KLUGBAUER, N., GRIESBECK, O., HAAS, A., MANN, M., BRACHER, F., TEUPSER, D., SAFTIG, P., BIEL, M. and WAHL-SCHOTT, C. (2014). High susceptibility to fatty liver disease in two-pore channel 2-deficient mice. Nat Commun 5: 4699.

GSTIR, R., SCHAFFERER, S., SCHEIDELER, M., MISSLINGER, M., GRIEHL, M., DASCHIL, N., HUMPEL, C., OBERMAIR, G. J., SCHMUCKERMAIR, C., STRIESSNIG, J., FLUCHER, B. E. and HUTTENHOFER, A. (2014). Generation of a neuro-specific microarray reveals novel differentially expressed noncoding RNAs in mouse models for neurodegenerative diseases. RNA20: 1929-1943.

GU, X. and SPITZER, N. C. (1995). Distinct aspects of nuronal differentiation encoded by frequency of spontaneous $\mathrm{Ca}^{2+}$ transients. Nature 375: 784-787.

HARADA, M., LUO, X., MUROHARA, T., YANG, B., DOBREV, D. and NATTEL, S. (2014). MicroRNA regulation and cardiac calcium signaling: role in cardiac disease and therapeutic potential. Circ Res 114: 689-705

HOGAN, P. G., CHEN, L., NARDONE, J. and RAO, A. (2003). Transcriptional regulation by calcium, calcineurin, and NFAT. Genes Dev 17: 2205-2232.

HOPPE, U. C. (2010). Mitochondrial calcium channels. FEBS Lett 584: 1975-1981.

HUANG, X., GODFREY, T. E., GOODING, W. E., MCCARTY, K. S., JR. and GOLLIN, S. M. (2006). Comprehensive genome and transcriptome analysis of the 11q13 amplicon in human oral cancer and synteny to the 7F5 amplicon in murine oral carcinoma. Genes Chromosomes Cancer 45: 1058-1069.

IKURA, M., OSAWA, M. and AMES, J. B. (2002). The role of calcium-binding proteins in the control of transcription: structure to function. Bioessays 24: 625-636.

ISHIBASHI, K., SUZUKI, M. and IMAI, M. (2000). Molecular cloning of a novel form (two-repeat) protein related to voltage-gated sodium and calcium channels. Biochem Biophys Res Commun 270: 370-376.

JANOWSKI, E., CLEEMANN, L., SASSE, P. and MORAD, M. (2006). Diversity of $\mathrm{Ca}^{2+}$ signaling in developing cardiac cells. Ann N Y Acad Sci 1080: 154-164.
JHA, A., AHUJA, M., PATEL, S., BRAILOIU, E. and MUALLEM, S. (2014). Convergent regulation of the lysosomal two-pore channel-2 by $\mathrm{Mg}^{2+}$, NAADP, $\mathrm{PI}(3,5) \mathrm{P}(2)$ and multiple protein kinases. EMBO J 33: 501-511.

KEGLEY, K. M., GEPHART, J., WARREN, G. L. and PAVLATH, G. K. (2001). Altered primary myogenesis in NFATC3-/- mice leads to decreased muscle size in the adult. Dev Biol 232: 115-126.

KELU, J. J., CHAN, H.L.H., WEBB, S.E., CHENG, A. H. H., RUAS, M., PARRINGTON J., GALIONE, A. and MILLER., A.L. (2015). Two-Pore Channel 2 activity is required for slow muscle cell-generated $\mathrm{Ca}^{2+}$ signaling during myogenesis in intact zebrafish. Int J Dev Biol 59: 313-325

KILPATRICK, B. S., EDEN, E. R., SCHAPIRA, A. H., FUTTER, C. E. and PATEL, S. (2013). Direct mobilisation of lysosomal $\mathrm{Ca}^{2+}$ triggers complex $\mathrm{Ca}^{2+}$ signals. J Cell Sci 126: 60-66.

KINNEAR, N. P., BOITTIN, F. X., THOMAS, J. M., GALIONE, A. and EVANS, A. M. (2004). Lysosome-sarcoplasmic reticulum junctions. A trigger zone for calcium signaling by nicotinic acid adenine dinucleotide phosphate and endothelin-1. $J$ Biol Chem 279: 54319-54326.

KINNEAR, N. P., WYATT, C. N., CLARK, J. H., CALCRAFT, P. J., FLEISCHER, S. JEYAKUMAR, L. H., NIXON, G. F. and EVANS, A. M. (2008). Lysosomes co-localize with ryanodine receptor subtype 3 to form a trigger zone for calcium signalling by NAADP in rat pulmonary arterial smooth muscle. Cell Calcium 44: 190-201.

KOSINIAK-KAMYSZ, A., MARCZAKIEWICZ-LUSTIG, A., MARCINSKA, M., SKOWRON, M., WOJAS-PELC, A., POSPIECH, E. and BRANICKI, W. (2014). Increased risk of developing cutaneous malignant melanoma is associated with variation in pigmentation genes and VDR, and may involve epistatic effects. Melanoma Res 24: 388-396.

KREUSSER, M. M. and BACKS, J. (2014). Integrated mechanisms of CaMKIIdependent ventricular remodeling. Front Pharmacol 5: 36.

LAM, A. K., GALIONE, A., LAI, F. A. and ZISSIMOPOULOS, S. (2013). Hax-1 identified as a two-pore channel (TPC)-binding protein. FEBS Lett 587: 3782-3786.

LEAR, P. V., GONZALEZ-TOUCEDA, D., PORTEIRO COUTO, B., VIANO, P., GUYMER, V., REMZOVA, E., TUNN, R., CHALASANI, A., GARCIA-CABALLERO, T., HARGREAVES, I. P., TYNAN, P. W., CHRISTIAN, H. C., NOGUEIRAS, R. PARRINGTON, J. and DIEGUEZ, C. (2014). Absence of intracellular ion channels TPC1 and 2 leads to mature-onset obesity in male mice, due to impaired lipid availability for thermogenesis in brown adipose tissue. Endocrinology 156:975-986.

LECLERC, C., NEANT, I. and MOREAU, M. (2012). The calcium: an early signal that initiates the formation of the nervous system during embryogenesis. Front Mol Neurosci 5: 3

LEE, H. C. (2003). Calcium signaling: NAADP ascends as a new messenger. Curr Biol 13: R186-R188.

LEE, H. C. (2012). Cyclic ADP-ribose and nicotinic acid adenine dinucleotide phosphate (NAADP) as messengers for calcium mobilization. J Biol Chem287:31633-31640.

LEE, H. C. and AARHUS, R. (1995). A derivative of NADP mobilizes calcium stores insensitive to inositol trisphosphate and cyclic ADP-ribose. J Biol Chem 270: 2152-2157.

LEE, H. C. and AARHUS, R. (2000). Functional visualization of the separate but interacting calcium stores sensitive to NAADP and cyclic ADP-ribose. J Cell Sci 113: 4413-4420.

LEWIS, R. S. (2007). The molecular choreography of a store-operated calcium channel. Nature 446: 284-287.

LIN, P. H., DUANN, P., KOMAZAKI, S., PARK, K. H., LI, H., SUN, M., SERMERSHEIM, M., GUMPPER, K., PARRINGTON, J., GALIONE, A., EVANS, A. M., ZHU, M. $\mathrm{X}$. and MA, J. (2014). Lysosomal two-pore channel subtype 2 (TPC2) regulates skeletal muscle autophagic signaling. J Biol Chem 290: 3377-3389.

LIN-MOSHIER, Y., WALSETH, T. F., CHURAMANI, D., DAVIDSON, S. M., SLAMA J. T., HOOPER, R., BRAILOIU, E., PATEL, S. and MARCHANT, J. S. (2012). Photoaffinity labeling of nicotinic acid adenine dinucleotide phosphate (NAADP) targets in mammalian cells. J Biol Chem 287: 2296-2307

LIN-MOSHIER, Y., KEEBLER, M. V., HOOPER, R., BOULWARE, M. J., LIU, X., CHURAMANI, D., ABOOD, M. E., WALSETH, T. F., BRAILOIU, E., PATEL, S. and MARCHANT, J. S. (2014) The Two-pore channel (TPC) interactome unmasks isoform-specific roles for TPCs in endolysosomal morphology and cell pigmentation. Proc Natl Acad Sci U S A 111: 13087-13092.

LLOYD-EVANS, E., MORGAN, A. J., HE, X., SMITH, D. A., ELLIOT-SMITH, E. SILLENCE, D. J., CHURCHILL, G. C., SCHUCHMAN, E. H., GALIONE, A. and 
PLATT, F. M. (2008). Niemann-Pick disease type C1 is a sphingosine storage disease that causes deregulation of lysosomal calcium. Nat Med 14: 1247-1255.

LOCKSHIN, R. A. and ZAKERI, Z. (2007). Cell death in health and disease. J Cell Mol Med 11: 1214-1224.

LU, Y., HAO, B. X., GRAEFF, R., WONG, C. W., WU, W. T. and YUE, J. (2013). Two pore channel 2 (TPC2) inhibits autophagosomal-lysosomal fusion by alkalinizing lysosomal pH. J Biol Chem 288: 24247-24263.

MENTEYNE, A., BURDAKOV, A., CHARPENTIER, G., PETERSEN, O. H. and CANCELA, J. M. (2006). Generation of specific $\mathrm{Ca}^{2+}$ signals from $\mathrm{Ca}^{2+}$ stores and endocytosis by differential coupling to messengers. Curr Biol 16: 1931-1937.

MIZUSHIMA, N. and KOMATSU, M. (2011). Autophagy: renovation of cells and tissues. Cell 147: 728-741.

MIZUSHIMA, N. and LEVINE, B. (2010). Autophagy in mammalian development and differentiation. Nat Cell Biol 12: 823-830.

MORENO-MOYA, J. M., VILELLA, F. and SIMON, C. (2014). MicroRNA: key gene expression regulators. Fertil Steril 101: 1516-1523.

MORGAN, A. J., DAVIS, L. C., WAGNER, S. K., LEWIS, A. M., PARRINGTON, J., CHURCHILL, G. C. and GALIONE, A. (2013). Bidirectional $\mathrm{Ca}^{2+}$ signaling occurs between the endoplasmic reticulum and acidic organelles. J Cell Biol200:789-805.

MORGAN, A. J. and GALIONE, A. (2007). Fertilization and nicotinic acid adenine dinucleotide phosphate induce $\mathrm{pH}$ changes in acidic $\mathrm{Ca}^{2+}$ stores in sea urchin eggs. J Biol Chem 282: 37730-37737.

MORGAN, A. J., PLATT, F. M., LLOYD-EVANS, E. and GALIONE, A. (2011). Molecular mechanisms of endolysosomal $\mathrm{Ca}^{2+}$ signalling in health and disease. Biochem J 439: 349-374

MORRIS, K. V. and MATTICK, J. S. (2014). The rise of regulatory RNA. Nat Rev Genet 15: 423-437.

MOUSTAKAS, A. and HELDIN, C. H. (2007). Signaling networks guiding epithelialmesenchymal transitions during embryogenesis and cancer progression. Cancer Sci 98: 1512-1520.

MURROW, L. and DEBNATH, J. (2013). Autophagy as a stress-response and quality-control mechanism: implications for cell injury and human disease. Annu Rev Pathol 8: 105-137.

NADER, N., KULKARNI, R. P., DIB, M. and MACHACA, K. (2013). How to make a good egg!: The need for remodeling of oocyte $\mathrm{Ca}^{2+}$ signaling to mediate the eggto-embryo transition. Cell Calcium 53: 41-54.

NAYLOR, E., ARREDOUANI, A., VASUDEVAN, S. R., LEWIS, A. M., PARKESH, R., MIZOTE, A., ROSEN, D., THOMAS, J. M., IZUMI, M., GANESAN, A., GALIONE, A. and CHURCHILL, G. C. (2009). Identification of a chemical probe for NAADP by virtual screening. Nat Chem Biol 5: 220-226.

NEELY KAYALA, K. M., DICKINSON, G. D., MINASSIAN, A., WALLS, K. C., GREEN, K. N. and LAFERLA, F. M. (2012). Presenilin-null cells have altered two-pore calcium channel expression and lysosomal calcium: implications for lysosomal function. Brain Res 1489: 8-16.

NITA, L. I., HERSHFINKEL, M. and SEKLER, I. (2015) Life after the birth of the mitochondrial $\mathrm{Na}^{+} / \mathrm{Ca}^{2+}$ exchanger, NCLX. Sci China Life Sci 58: 59-65.

NIXON, R. A. and YANG, D. S. (2011) Autophagy failure in Alzheimer's disease-locating the primary defect. Neurobiol Dis 43: 38-45.

NOMIKOS, M., SWANN, K. and LAI, F. A. (2012). Starting a new life: sperm PLC-zeta mobilizes the $\mathrm{Ca}^{2+}$ signal that induces egg activation and embryo development: an essential phospholipase $\mathrm{C}$ with implications for male infertility. Bioessays 34: 126-134.

NOTOMI, T., EZURA, Y. and NODA, M. (2012). Identification of two-pore channel 2 as a novel regulator of osteoclastogenesis. J Biol Chem 287: 35057-35064.

NTAMBI, J. M. and TAKOVA, T. (1996). Role of $\mathrm{Ca}^{2+}$ in the early stages of murine adipocyte differentiation as evidenced by calcium mobilizing agents. Differentiation 60: 151-158.

OGUNBAYO, O. A., ZHU, Y., SHEN, B., AGBANI, E., LI, J., MA, J., ZHU, M. X. and EVANS, A. M. (2015). Organelle-specific subunit interactions of the vertebrate two-pore channel family. J Biol Chem 290: 1086-1095.

ORCIANI, M., TRUBIANI, O., GUARNIERI, S., FERRERO, E. and DI PRIMIO, R. (2008). CD38 is constitutively expressed in the nucleus of human hematopoietic cells. J Cell Biochem 105: 905-912.

PARK, K.H., KIM, K.N., PARK, D.R, JANG, K.Y. and KIM, U.H. (2015). Role of nicotinic acid adenine dinucleotide phosphate (NAADP) in keratinocyte differentiation. $J$
Invest Dermatol [In Press]

PARRINGTON, J., DAVIS, L. C., GALIONE, A. and WESSEL, G. (2007). Flipping the switch: how a sperm activates the egg at fertilization. Dev Dyn 236: 2027-2038.

PATEL, S. and DOCAMPO, R. (2010). Acidic calcium stores open for business: expanding the potential for intracellular $\mathrm{Ca}^{2+}$ signaling. Trends Cell Biol 20: 277-286.

PATEL, S., RAMAKRISHNAN, L., RAHMAN, T., HAMDOUN, A., MARCHANT, J. S., TAYLOR, C. W. and BRAILOIU, E. (2011). The endo-lysosomal system as an NAADP-sensitive acidic $\mathrm{Ca}^{2+}$ store: role for the two-pore channels. Cell Calcium 50: 157-167.

PENDIN, D., GREOTTI, E. and POZZAN, T. (2014). The elusive importance of being a mitochondrial $\mathrm{Ca}^{2+}$ uniporter. Cell Calcium 55: 139-145.

PENNY, C. J., KILPATRICK, B. S., MIN HAN, J., SNEYD, J. and PATEL, S. (2014). A mix-and-match approach to designing $\mathrm{Ca}^{2+}$ microdomains at membrane-contact sites. Commun Integr Biol 7: e29586.

PEREIRA, G. J., HIRATA, H., FIMIA, G. M., DO CARMO, L. G., BINCOLETTO, C., HAN, S. W., STILHANO, R. S., URESHINO, R. P., BLOOR-YOUNG, D., CHURCHILL, G., PIACENTINI, M., PATEL, S. and SMAILI, S. S. (2011) Nicotinic acid adenine dinucleotide phosphate (NAADP) regulates autophagy in cultured astrocytes. $J$ Biol Chem 286: 27875-27881.

PHO, L. N. and LEACHMAN, S. A. (2010). Genetics of pigmentation and melanoma predisposition. G Ital Dermatol Venereol 145: 37-45.

PITT, S. J., FUNNELL, T. M., SITSAPESAN, M., VENTURI, E., RIETDORF, K., RUAS, M., GANESAN, A., GOSAIN, R., CHURCHILL, G. C., ZHU, M.X., PARRINGTON, J., GALIONE, A. and SITSAPESAN, R. (2010) TPC2 is a novel NAADP-sensitive $\mathrm{Ca}^{2+}$ release channel, operating as a dual sensor of luminal $\mathrm{pH}$ and $\mathrm{Ca}^{2+}$. $\mathrm{J} \mathrm{BiOl}$ Chem 285: 35039-35046.

PITT, S. J., LAM, A. K., RIETDORF, K., GALIONE, A. and SITSAPESAN, R. (2014) Reconstituted human TPC1 is a proton-permeable ion channel and is activated by NAADP or $\mathrm{Ca}^{2+}$. Sci Signal 7: ra46.

PORTER, G. A., JR., MAKUCK, R. F. and RIVKEES, S. A. (2002). Reduction in intracellular calcium levels inhibits myoblast differentiation. $J$ Biol Chem 277: 28942-28947.

RAHMAN, T., CAI, X., BRAILOIU, G. C., ABOOD, M. E., BRAILOIU, E. and PATEL, S. (2014) Two-pore channels provide insight into the evolution of voltage-gated $\mathrm{Ca}^{2+}$ and $\mathrm{Na}^{+}$channels. Sci Signal 7: ra109.

RAMOS, I., REICH, A. and WESSEL, G. M. (2014). Two-pore channels function in calcium regulation in sea star oocytes and embryos. Development 141: 4598-4609.

ROSEN, D., LEWIS, A. M., MIZOTE, A., THOMAS, J. M., ALEY, P. K., VASUDEVAN, S. R., PARKESH, R., GALIONE, A., IZUMI, M., GANESAN, A. and CHURCHILL, G. C. (2009). Analogues of the nicotinic acid adenine dinucleotide phosphate (NAADP) antagonist Ned-19 indicate two binding sites on the NAADP receptor. $J$ Biol Chem 284: 34930-34934.

RUAS, M., RIETDORF, K., ARREDOUANI, A., DAVIS, L. C., LLOYD-EVANS, E. KOEGEL, H., FUNNELL, T. M., MORGAN, A. J., WARD, J. A., WATANABE, K. CHENG, X., CHURCHILL, G. C., ZHU, M. X., PLATT, F. M., WESSEL, G. M., PARRINGTON, J. and GALIONE, A. (2010). Purified TPC isoforms form NAADP receptors with distinct roles for $\mathrm{Ca}^{2+}$ signaling and endolysosomal trafficking. Curr Biol 20: 703-709.

RUAS, M., CHUANG, K. T., DAVIS, L. C., AL-DOURI, A., TYNAN, P. W., TUNN, R. TEBOUL, L., GALIONE, A. and PARRINGTON, J. (2014). TPC1 has two variant isoforms, and their removal has different effects on endo-lysosomal functions compared to loss of TPC2. Mol Cell Biol 34: 3981-3992.

RUAS, M., DAVIS, L.C., CHEN,C.C., MORGAN, A.J., CHUANG, K.T.,WALSETH, T.F., GRIMM, C., GARNHAM, C., POWELL, T., PLATT, N., PLATT, F.M., BIEL, M., WAHL-SCHOTT, C., PARRINGTON, J. and GALIONE, A. (2015). Selective rescue of NAADP-signalling in TPC-null cells by $\mathrm{Ca}^{2+}$-permeable TPCs. EMBO Journal pii: e201490009. [Epub ahead of print]

RYBALCHENKO, V., AHUJA, M., COBLENTZ, J., CHURAMANI, D., PATEL, S. KISELYOV, K. and MUALLEM, S. (2012) Membrane potential regulates nicotinic acid adenine dinucleotide phosphate (NAADP) dependence of the $\mathrm{pH}-$ - and $\mathrm{Ca}^{2+}$-sensitive organellar two-pore channel TPC1. J Biol Chem 287: 20407-16.

SAKURAI, Y., KOLOKOLTSOV, A.A., CHEN, C.C., TIDWELL, M.W., BAUTA, W.E., KLUGBAUER, N., GRIMM C., WAHL-SCHOTT, C., BIEL, M. and DAVEY, R.A. (2015) Ebola virus. Two-pore channels control Ebola virus host cell entry and are drug targets for disease treatment. Science. 347: 995-998.

SANDRI, M. (2010). Autophagy in health and disease. 3. Involvement of autophagy 
in muscle atrophy. Am J Physiol Cell Physiol 298: C1291-1297.

SANTELLA, L., KYOZUKA, K., GENAZZANI, A. A., DE RISO, L. and CARAFOLI, E. (2000). Nicotinic acid adenine dinucleotide phosphate-induced $\mathrm{Ca}^{2+}$ release. Interactions among distinct $\mathrm{Ca}^{2+}$ mobilizing mechanisms in starfish oocytes. $J$ Biol Chem 275: 8301-8306.

SANTELLA, L., VASILEV, F. and CHUN, J. T. (2012). Fertilization in echinoderms. Biochem Biophys Res Commun 425: 588-594.

SHAYWITZ, A. J. and GREENBERG, M. E. (1999). CREB: a stimulus-induced transcription factor activated by a diverse array of extracellular signals. Annu Rev Biochem 68: 821-861.

SHEN, D., WANG, X. and XU, H. (2011). Pairing phosphoinositides with calcium ions in endolysosomal dynamics: phosphoinositides control the direction and specificity of membrane trafficking by regulating the activity of calcium channels in the endolysosomes. Bioessays 33: 448-457.

SHI, H., HALVORSEN, Y. D., ELLIS, P. N., WILKISON, W. O. and ZEMEL, M. B. (2000). Role of intracellular calcium in human adipocyte differentiation. Physiol Genomics 3: 75-82.

STURM, R. A. (2009). Molecular genetics of human pigmentation diversity. Hum Mol Genet 18: R9-17.

SUGAHARA, K., MICHIKAWA, Y., ISHIKAWA, K., SHOJI, Y., IWAKAWA, M., SHIBAHARA, T. and IMAI, T. (2011). Combination effects of distinct cores in 11q13 amplification region on cervical lymph node metastasis of oral squamous cell carcinoma. Int J Oncol 39: 761-769.

SUN, L., IQBAL, J., DOLGILEVICH, S., YUEN, T., WU, X. B., MOONGA, B. S., ADEBANJO, O. A., BEVIS, P. J., LUND, F., HUANG, C. L., BLAIR, H. C., ABE, E. and ZAIDI, M. (2003). Disordered osteoclast formation and function in a CD38 (ADP-ribosyl cyclase)-deficient mouse establishes an essential role for CD38 in bone resorption. FASEB J 17: 369-375.

TUGBA DURLU-KANDILCI, N., RUAS, M., CHUANG, K. T., BRADING, A., PARRINGTON, J. and GALIONE, A. (2010). TPC2 proteins mediate nicotinic acid adenine dinucleotide phosphate (NAADP)- and agonist-evoked contractions of smooth muscle. J Biol Chem 285: 24925-24932.

WAKAI, T., VANDERHEYDEN, V. and FISSORE, R. A. (2011). $\mathrm{Ca}^{2+}$ signaling during mammalian fertilization: requirements, players, and adaptations. Cold Spring Harb Perspect Biol 3: a006767.

WALSETH, T. F., LIN-MOSHIER, Y., JAIN, P., RUAS, M., PARRINGTON, J., GALIONE, A., MARCHANT, J. S. and SLAMA, J. T. (2012). Photoaffinity labeling of high affinity nicotinic acid adenine dinucleotide phosphate (NAADP)-binding proteins in sea urchin egg. J Biol Chem 287: 2308-2315.

WALLINGFORD, J. B., EWALD, A. J., HARLAND, R. M., and FRASER, S. E. (2001) Calcium signaling during convergent extension in Xenopus. Curr Biol 11: 652-61.

WANG, X., ZHANG, X., DONG, X. P., SAMIE, M., LI, X., CHENG, X., GOSCHKA, A., SHEN, D., ZHOU, Y., HARLOW, J., ZHU, M. X., CLAPHAM, D. E., REN, D. and $\mathrm{XU}, \mathrm{H}$. (2012). TPC proteins are phosphoinositide- activated sodium-selective ion channels in endosomes and lysosomes. Cell 151: 372-383.

WEBB, S.E., LEE, K. W., KARPLUS, E. and MILLER, A.L. (1997) Localized calcium transients accompany furrow positioning, propagation and deepening during the early cleavage period of zebrafish embryos. Dev. Biol. 192: 78-92.

WU, M. M., LUIK, R. M. and LEWIS, R. S. (2007). Some assembly required: constructing the elementary units of store-operated $\mathrm{Ca}^{2+}$ entry. Cell Calcium 42: 163-172.

WU, X., WON, H. and RUBINSZTEIN, D. C. (2013). Autophagy and mammalian development. Biochem Soc Trans 41: 1489-1494.

XIONG, J., XIA, M., XU, M., ZHANG, Y., ABAIS, J. M., LI, G., RIEBLING, C. R., RITTER, J. K., BOINI, K. M. and LI, P. L. (2013). Autophagy maturation associated with CD38-mediated regulation of lysosome function in mouse glomerular podocytes. J Cell Mol Med 17: 1598-1607.

XU, M., LI, X. X., CHEN, Y., PITZER, A. L., ZHANG, Y. and LI, P. L. (2014). Enhancement of dynein-mediated autophagosome trafficking and autophagy maturation by ROS in mouse coronary arterial myocytes. J Cell Mol Med 18: 2165-2175.

XU, M., LI, X. X., XIONG, J., XIA, M., GULBINS, E., ZHANG, Y. and LI, P. L. (2013). Regulation of autophagic flux by dynein-mediated autophagosomes trafficking in mouse coronary arterial myocytes. Biochim Biophys Acta 1833: 3228-3236.

XU, Q., YU, L., LIU, L., CHEUNG, C. F., LI, X., YEE, S. P., YANG, X. J. and WU, Z. (2002). p38 Mitogen-activated protein kinase-, calcium-calmodulin-dependent protein kinase-, and calcineurin-mediated signaling pathways transcriptionally regulate myogenin expression. Mol Biol Cell 13: 1940-1952.

YALCINTEPE, L., ALBENIZ, I., ADIN-CINAR, S., TIRYAKI, D., BERMEK, E., GRAEFF, R. M. and LEE, H. C. (2005). Nuclear CD38 in retinoic acid-induced HL-60 cells. Exp Cell Res 303: 14-21.

YAMASAKI, M., MASGRAU, R., MORGAN, A. J., CHURCHILL, G. C., PATEL, S., ASHCROFT, S. J. and GALIONE, A. (2004). Organelle selection determines agonistspecific $\mathrm{Ca}^{2+}$ signals in pancreatic acinar and $\beta$ cells. J Biol Chem 279: 7234-7240.

YOSHIBA, S. and HAMADA, H. (2014). Roles of cilia, fluid flow, and $\mathrm{Ca}^{2+}$ signaling in breaking of left-right symmetry. Trends Genet 30: 10-17.

YOUNG, K. W. and NAHORSKI, S. R. (2002). Sphingosine 1-phosphate: a Ca ${ }^{2+}$ release mediator in the balance. Cell Calcium 32: 335-341.

ZHANG, Y., XU, M., XIA, M., LI, X., BOINI, K. M., WANG, M., GULBINS, E., RATZ, P. H. and LI, P. L. (2014). Defective autophagosome trafficking contributes to impaired autophagic flux in coronary arterial myocytes lacking CD38 gene. Cardiovasc Res 102: 68-78.

ZHANG, Z. H., LU, Y. Y. and YUE, J. (2013). Two pore channel 2 differentially modulates neural differentiation of mouse embryonic stem cells. PLoS One 8: e66077.

ZHU, M. X., MA, J., PARRINGTON, J., CALCRAFT, P. J., GALIONE, A. and EVANS, A. M. (2010). Calcium signaling via two-pore channels: local or global, that is the question. Am J Physiol Cell Physiol 298: C430-441.

ZOIS, C. E., GIATROMANOLAKI, A., SIVRIDIS, E., PAPAIAKOVOU, M., KAINULAINEN, H. and KOUKOURAKIS, M. I. (2011). Autophagic flux in normal mouse tissues: focus on endogenous LC3A processing. Autophagy 7: 1371-1378.

ZONG, X., SCHIEDER, M., CUNY, H., FENSKE, S., GRUNER, C., ROTZER, K., GRIESBECK, O., HARZ, H., BIEL, M. and WAHL-SCHOTT, C. (2009). The twopore channel TPCN2 mediates NAADP-dependent $\mathrm{Ca}^{2+}$-release from lysosomal stores. Pflugers Arch 458: 891-899. 
356 J. Parrington et al. 


\section{Further Related Reading, published previously in the Int. J. Dev. Biol.}

Egg activation in physiologically polyspermic newt eggs: involvement of $\mathrm{IP}_{3}$ receptor, PLCy, and microtubules in calcium wave induction

Tomoyo Ueno, Takehiro Ohgami, Yuichirou Harada, Shuichi Ueno and Yasuhiro Iwao

Int. J. Dev. Biol. (2014) 58: 315-323

Visualization, characterization and modulation of calcium signaling during the development of slow muscle cells in intact zebrafish embryos

Chris Y. Cheung, Sarah E. Webb, Donald R. Love and Andrew L. Miller

Int. J. Dev. Biol. (2011) 55: 153-174

Could modifications of signalling pathways activated after ICSI induce a potential risk of epigenetic defects?

Brigitte Ciapa and Christophe Arnoult

Int. J. Dev. Biol. (2011) 55: 143-152

Oscillatory $\mathrm{Ca}^{2+}$ dynamics and cell cycle resumption at fertilization in mammals: a modelling approach Geneviève Dupont, Elke Heytens and Luc Leybaert

Int. J. Dev. Biol. (2010) 54: 655-665

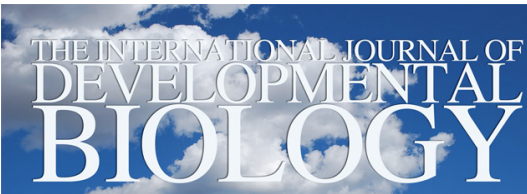

Volume 56 Nos. 10/11/12 Special Issue
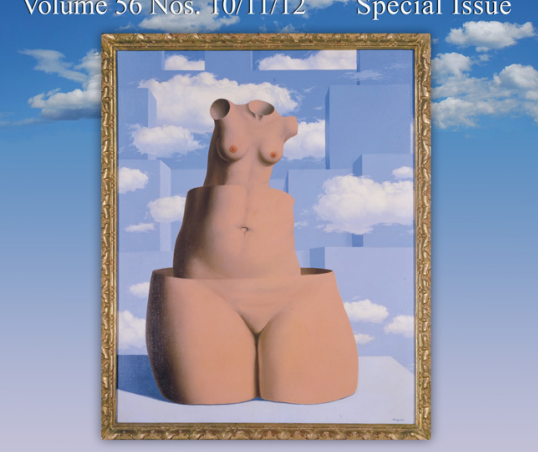

Female Germ Cells in Development \& Tumors

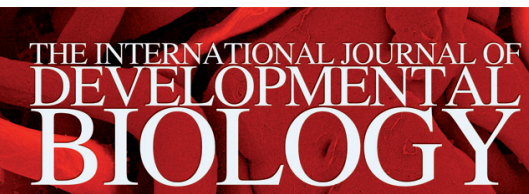

Volume 57 Nos, 2/3/4

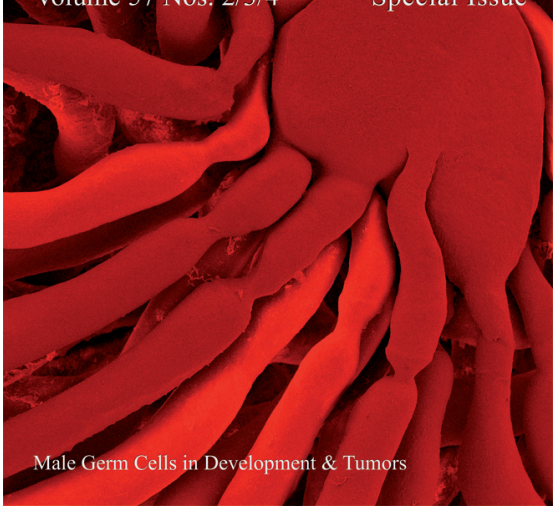

The role of ion fluxes in polarized cell growth and morphogenesis: the pollen tube as an experimental paradigm

Erwan Michard, Filipa Alves and José A. Feijó

Int. J. Dev. Biol. (2009) 53: 1609-1622

Sperm-activating peptides in the regulation of ion fluxes, signal transduction and motility

Alberto Darszon, Adán Guerrero, Blanca E. Galindo, Takuya Nishigaki and Christopher D. Wood

Int. J. Dev. Biol. (2008) 52: 595-606

The dynamics of calcium oscillations that activate mammalian eggs

Karl Swann and Yuansong Yu

Int. J. Dev. Biol. (2008) 52: 585-594

The choice between epidermal and neural fate: a matter of calcium. Marc Moreau and Catherine Leclerc

Int. J. Dev. Biol. (2004) 48: 75-84
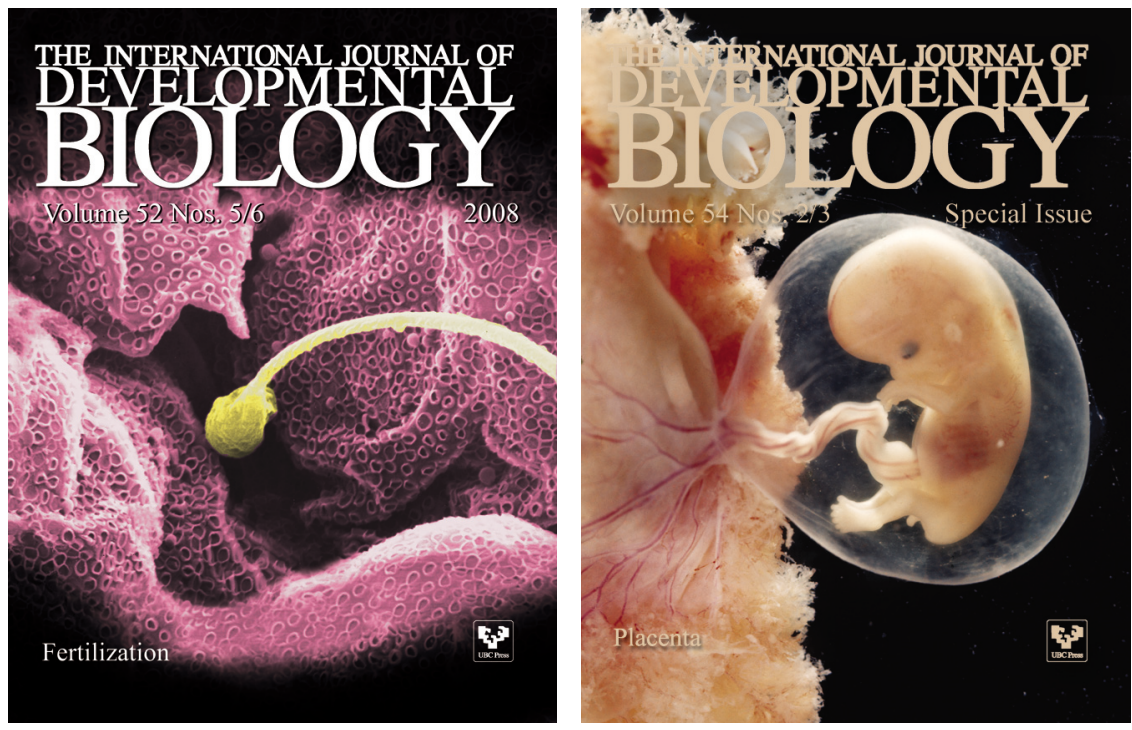